UNIVERSIDADE DE BRASÍLIA

Dissertação de Mestrado

\title{
Estudo da crosta e do manto superior sob a porção leste da Plataforma Sul-Americana utilizando tomografia sísmica de ruído ambiental
}

Autor:

Marcos Vinícius FerReIRA
Orientador:

Dr. Marcelo Peres RochA 
"Most people, if you describe a train of events to them, will tell you what the result would be. There are few people, however, who, if you told them a result, would be able to evolve from their own inner consciousness what the steps were which led up to that result. This power is what $i$ mean when $i$ talk of reasoning backwards."

Sherlock Holmes, in A Study in Scarlet by Arthur Conan Doyle 


\section{Resumo}

A tomografia de ruído ambiental foi utilizada para estudar a crosta e o manto superior sob a porção sudeste da plataforma Sul-Americana. Este método foi escolhido devida a baixa distribuição espacial de eventos símicos na região e a dificuldade de obter períodos menores (inferiores a $30 \mathrm{~s}$ ) para os eventos. Neste trabalho focou-se nas ondas Rayleigh que foram extraídas das Funções de Green obtidas a partir da correlação cruzada de fase (PCC) das componentes verticais dos registros das estações sismográficas. As correlações obtidas foram empilhadas utilizando a técnica do empilhamento de fase com pesos (tfPWS). Estes métodos realçam sinais fracos aumentando as chances de detectá-los, além de conseguir detectar sinais mascarados por grandes amplitudes e aumentar a razão sinal ruído. Serão apresentados mapas de velocidade de grupo para vários períodos que representam a contribuição de velocidade para profundidades de até $40 \mathrm{~km}$. 


\section{Abstract}

The Ambient Noise Tomography technique was employed to study the crust and the shallow mantle under the southeast portion of the South American Platform. This method was chosen due to the poor spatial distribution of ray paths which would be obtained for earthquake surface wave tomography at periods which range from 5 s to 20 s. In this work, we focus on Rayleigh waves which are extracted from empirical Green's functions which we obtain from the phase cross-correlations (PCC) of vertical component ambient noise recordings. PCC is based on the instantaneous phase coherence of the analytic signals and was chosen since it is amplitude unbiased. The obtained cross-correlations were then stacked using the time-frequency domain Phase Weighted Stacking (tf-PWS). These methods are expected to detect and to enhance weak, but coherent signals concealed in other larger amplitude signals and to improve the signalto-noise ratio of the final results. Here, we will present group velocity maps several periods which represent the average structure down to depth of about $40 \mathrm{~km}$. 


\section{Agradecimentos}

Primeiramente eu agradeço ao meu orientador Prof. Dr. Marcelo Peres Rocha que me orientou e ajudou imensamente mostrando paciência e compreensão, além dos ensinamentos e conselhos que foram dados.

Agradeço também a todos os professores que tive o contato e a oportunidade de aprender com eles, afinal, são com somas infinitesimais que se constrói o conhecimento.

Também gostaria de agradecer a Secretaria de Pós-Graduação, técnicos e funcionários do Instituto de Geociências da UnB que ajudaram nos procedimentos, permitido a finalização desta dissertação.

Aos amigos que sempre contribuiriam e apoiaram este trabalho, especialmente Iago Costa e Isabelle Serafim cujo o incetivo foi fundamental. 


\section{Sumário}

Resumo ii

Abstract $\quad$ iii

Agradecimentos iv

Sumário $\quad$ v

Lista de Figuras vii

$\begin{array}{lll}1 & \text { Introdução } & 1\end{array}$

1.1 Introdução . . . . . . . . . . . . . . . . . . . . . . . . . . . . 1

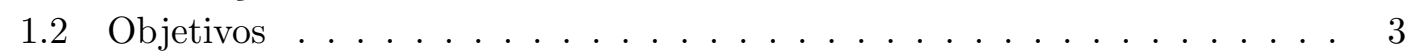

1.3 Área de Estudo e Contexto Geológico . . . . . . . . . . . . . . . . . . . . . . . 4

1.4 Estações Sismográficas . . . . . . . . . . . . . . . . . . . . . . 5

\begin{tabular}{llr|}
2 & Revisão Bibliográfica & $\mathbf{7}$
\end{tabular}

2.1 Caracterização das Ondas Sísmicas . . . . . . . . . . . . . . . . . . . . 7

2.2 Caracterização do Ruído Ambiental . . . . . . . . . . . . . . . . . . . . . . . . . . 10

2.3 Função de Green . . . . . . . . . . . . . . . . . . . . . . . . . . . . . . . . . . . . . . . . . . . . . . . . . . . .

$2.4 \quad$ Inversão $\ldots \ldots \ldots \ldots \ldots \ldots \ldots$

\begin{tabular}{lll}
\hline 3 & Metodologia & 18
\end{tabular}

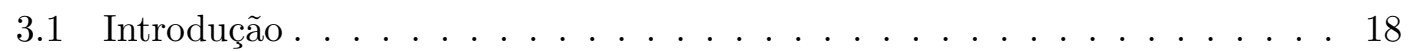

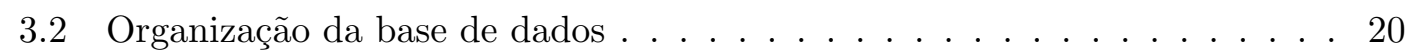

3.2 .1 Dados Brutos . . . . . . . . . . . . . . . . . . . . 20

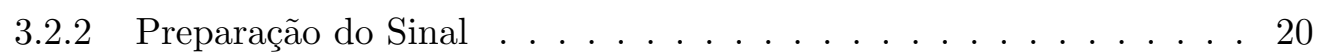

3.3 Correlação cruzada e empilhamento . . . . . . . . . . . . . . . . . . . . . . . . . . . 20

3.3 .1 Cálculo da correlação cruzada . . . . . . . . . . . . . . . . . . 20

3.3.2 Empilhamento diário das correlações cruzadas. . . . . . . . . . . . 21

3.4 Medida das curvas de dispersão $\ldots \ldots \ldots \ldots \ldots$. . . . . . . . . . . . . . . . . . . . . . . 22

3.4 .1 Medida da Velocidade de Grupo . . . . . . . . . . . . . . . . . . . . . . . . . . 22

3.5 Controle de Qualidade . . . . . . . . . . . . . . . . . . . . 23

3.5 .1 Correção de Erros e seleção de medidas aceitáveis . . . . . . . . . . 23

3.6 Inversão dos dados . . . . . . . . . . . . . . . . . . . . . 24 
3.6 .1 Inversão . . . . . . . . . . . . . . . . . . . . . . . 24

\begin{tabular}{|l|l|}
\hline Descrição dos Resultados & 27
\end{tabular} 4.1 Introdução . . . . . . . . . . . . . . . . . . . . . . . . . . . . . . . . . . . . . . . . . . . . .

4.2 Resultados ANT . . . . . . . . . . . . . . . . . . . . . . . 27

4.3 Resultados ANT e Tomografia de ondas de superfície (SW) . . . . . . . . 29

\begin{tabular}{|lll}
5 & Discussão dos Resultados & 42
\end{tabular}

5.1 Introdução . . . . . . . . . . . . . . . . . . . . . . 42

5.2 Bacias Sedimentares . . . . . . . . . . . . . . . . . . . . . . . . . . . . . . . . . . . 44

5.3 Faixas Móveis e Cráton do São Francisco . . . . . . . . . . . . . . . . . 44

\begin{tabular}{llr}
\hline 6 & Conclusões & 50
\end{tabular}

\begin{tabular}{ll}
\hline Referências Bibliográficas & 52
\end{tabular} 


\section{Lista de Figuras}

1.1 Cartograma de estações sismológicas $\ldots \ldots \ldots$. . . . . . . . . . . . 6

$2.1 \quad$ Dispersão Teórica $\ldots \ldots \ldots \ldots \ldots$

2.2 Sensibilidade . . . . . . . . . . . . . . . . . . . . . . . 10

2.3 Diagrama de Correlação . . . . . . . . . . . . . . . . . . . . . . . 13

3.1 Convergência do empilhamento . . . . . . . . . . . . . . . . . . . . . . . . 19

3.2 Etapas de processamento ANT . . . . . . . . . . . . . . . . . . . . . . 19

3.3 Correlação de dados 24 horas $\ldots \ldots \ldots \ldots$. . . . . . . . . . . . . . . . . . . . . . . . . . . . . . .

3.4 Empilhamento dos dados pra vários dias . . . . . . . . . . . . . . . . 22

3.5 Controle de qualidade . . . . . . . . . . . . . . . . . . . . . . . . . . . . . . . 24

3.6 Variação do parâmetro de suavidade . . . . . . . . . . . . . . . . . 26

$4.1 \quad$ Mapa de velocidade de grupo para o período de $5 \mathrm{~s}$. . . . . . . . . . . . . 30

4.2 Mapa de velocidade de grupo para o período de $10 \mathrm{~s}$. . . . . . . . . . . . . . 31

$4.3 \quad$ Mapa de velocidade de grupo para o período de $15 \mathrm{~s}$. . . . . . . . . . . . 32

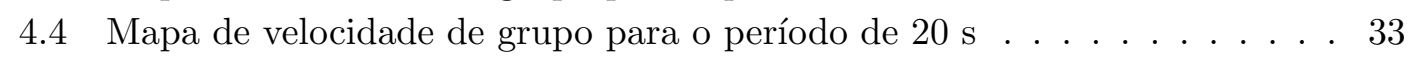

$4.5 \quad$ Mapa de velocidade de grupo para o período de $25 \mathrm{~s}$. . . . . . . . . . . . . . . 34

$4.6 \quad$ Mapa de velocidade de grupo para o período de $30 \mathrm{~s}$. . . . . . . . . . . . . . 35

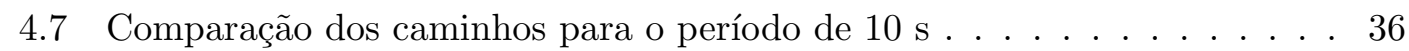

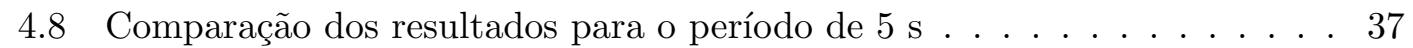

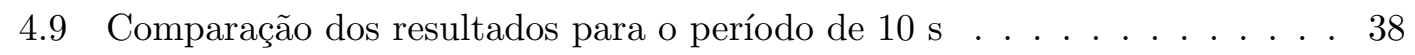

4.10 Comparação dos resultados para o período de $15 \mathrm{~s}$. . . . . . . . . . . . . 39

4.11 Comparação dos resultados para o período de $20 \mathrm{~s}$. . . . . . . . . . . . . 40

4.12 Comparação dos resultados para o período de $25 \mathrm{~s}$. . . . . . . . . . . 41

5.1 Comparação de ANT e Bacias sedimentares . . . . . . . . . . . . . . 46

5.2 Comparação de ANT e Gravimetria . . . . . . . . . . . . . . . . . . . . . . . . . . . . . .

5.3 Comparação entre Tomografias CSF . . . . . . . . . . . . . . . . 48

$\begin{array}{lll}5.4 & \text { Espessura Crustal } \ldots \ldots \ldots & \ldots\end{array} \ldots \ldots \ldots$ 
Para todos aqueles que me ajudaram a chegar neste ponto... 


\section{Capítulo 1}

\section{Introdução}

\subsection{Introdução}

Este trabalho de mestrado propõe identificar as diferentes unidades geológicas da parte leste da Plataforma Sul-Americana e inferir sobre a evolução geológica da região, com respeito à sua distribuição de velocidades, utilizando-se os registros do ruído sísmico registrado pelas estações sismográficas instaladas na região.

A tomografia sísmica de ruído ambiental (ANT - Ambient Noise Tomography) não utiliza fontes ativas para a geração de ondas, e sim o ruído sísmico da Terra, que pode ser gerado por ondas do mar, movimentação tectônica, fluxo de fluídos e todo tipo de ondas dispersas em todo o planeta. Para se obter o sinal utiliza-se da técnica de interferometria sísmica, onde após as correlações cruzadas dos registros simultâneos de pares de estações se recupera a função de Green da onda de superfície dispersa no meio. O desenvolvimento desta teoria, aliada ao desenvolvimento paralelo das técnicas de inversão voltadas ao estudo do interior da Terra (tomografia sísmica), e também aos avanços ocorridos na tecnologia computacional, que viabilizaram a implementação de soluções de grandes sistemas lineares numericamente, permitiu o surgimento de uma nova técnica de tomografia sísmica.

A partir disto utiliza-se dos procedimentos de análise das ondas superficiais para se gerar mapas de velocidade de grupo ou fase com relação à frequência e a profundidade da crosta. Esta metodologia é útil em regiões com baixa sismicidade, como é o caso do Brasil, já que não necessita de fontes a ser aplicada.

Na última década, o ruído sísmico ambiental, geralmente tratado como indesejado nos registros, passou a ser utilizado como fonte de informação para estudos da estrutura interna da Terra, ganhando destaque, especialmente para estudos de tomografia 
sísmica (SHAPIRO; CAMPILLO, 2004). A teoria que permitiu isso teve o início do seu desenvolvimento na área de Sismologia na década 1950, pela definição do ruído sísmico apresentada no trabalho de Aki (1957). Em um trabalho teórico, Claerbout (1968) propôs que a correlação cruzada de séries temporais, registradas simultaneamente por dois receptores, corresponderia ao sismograma de registro das ondas de superfície que teriam se propagado entre eles, analogamente ao caso evento-estação. Ou seja, a função de correlação cruzada representaria a resposta do meio à passagem das ondas. Posteriormente, esta proposta foi provada em uma aplicação na área de Astronomia para determinação de informações sobre a superfície solar (RICKETT; CLAERBOUT, 1999), ao se correlacionar registros do movimento aleatório da mesma (campo de pesquisa denominado como heliosismologia).

Vantagens de se utilizar ANT segundo Bensen et al. (2007) são: 1) Medidas realizadas usando ondas de superfície de forma tradicional possuem uma direção preferencial devido a localização dos terremotos, porém com a ANT é possível montar uma rede sismográfica que cobre todas as direções para realizar um imageamento de forma mais completa e homogênea. 2) Na tomografia tradicional é necessário conhecer informações da fonte, tais como a sua localização, que muitas vezes não é muito precisa, já na ANT a localização e a intensidade da fonte é de pouca importância. 3) Os dados obtidos a partir de terremotos muitas vezes percorrem grandes distâncias, logo as velocidades são uma média de todo esse caminho o que limita a resolução dos modelos que podem ser obtidos. Porém com a ANT essa resolução é definida pela rede sismográfica utilizada. além disso, pode ser feito um arranjo específico para o estudo de áreas de interesse. 4) A dispersão em períodos pequenos, até 40s, são difíceis de se obter utilizando métodos tradicionais de telessísmicos devido a atenuação e o espalhamento que ocorre das fontes distantes além das diferentes chegadas que estão mascaradas por chegadas de outros caminhos. A ANT fornece uma metodologia para imagear de maneira robusta períodos que estão contidos na crosta terrestre. Portanto, a ANT possui a capacidade de fornecer mapas de estrutura crustais com maior resolução vertical e horizontal do que métodos de tomografia tradicionais.

Diversos trabalhos utilizando este método tomográfico foram realizados em várias partes do mundo, fornecendo valiosas informações sobre a geologia a partir do comportamento sísmico em subsuperfície. Na Califórnia (EUA), utilizando a ANT (SHAPIRO et al. 2005), foram delimitadas as principais bacias sedimentares da região, a partir da análise do mapa de período de 7.5 s correspondente à parte rasa da crosta ( 5 até $10 \mathrm{~km}$ ), e as anomalias de alta velocidade observadas no mapa de $15 \mathrm{~s}$ na parte intermediária da crosta (10 até $20 \mathrm{~km}$ ) foram associadas ao arco vulcânico Mesozoico de Sierra Nevada. Neste trabalho foi possível inferir que os limites da península correspondem aos batólitos graníticos do Cretáceo, e que, devido à região do deserto de Mojave apresentar baixa velocidade, esta deve estar relacionada a uma crosta intermediária mais fraca e quente 
do que de Sierra Nevada. Na Coreia do Sul (CHO et al. 2007), os resultados da ANT permitiram refinar o modelo geológico existente da bacia de Gyeongsang. Na Europa (YANG et al., 2007), obteve-se boa concordância entre os mapas de tomografia e os de geologia local, sendo que as bacias conhecidas foram melhor delimitadas. Variações de velocidade observadas nos mapas tomográficos foram interpretadas como diferenças laterais na estruturação geológica em profundidades crustais. Vários outros exemplos de aplicação da ANT pelo mundo podem ser encontrados como por exemplo na Nova Zelândia (LIN et al., 2007), Península Ibérica (NOR et al., 2007), Tibete (YAO; HILST; MAARTEN, 2006).

No Brasil, a técnica foi aplicada em diversos contextos geológicos. Entre estes destacam-se os trabalhos realizados na região nordeste do país, especialmente na Província Borborema (DIAS; JULIÀ; SCHIMMEL, 2015, ROCHA et al., 2012), na Bacia do Paraná (COLLAÇO et al. 2012) e o trabalho do Goutorbe, Coelho e Drouet (2015) que apresentam um panorama geral da parte leste do Brasil. Os trabalhos sobre a bacia do Paraná (COLLAÇO et al., 2012) apresenta a metodologia de processamento dos dados que está sendo aplicada e os primeiros resultados da inversão para os períodos de 10 a 30s que concordam com resultados obtidos pela inversão da Onda de Superfície realizado por (FENG; ASSUMPÇAO; LEE, 2004). O trabalho sobre a província Borborema DIAS; JULIÀ; SCHIMMEL, 2015) discute a origem do ruído que está sendo utilizado, além de mostrar a metodologia em uso. Em Rocha et al. (2012) foram apresentados mapas de velocidade de grupo da onda Rayleigh para os períodos de 10, 15 e 20 segundos. No último, a anomalia de alta velocidade encontrada na parte nordeste da Província foi interpretada como o núcleo Arqueano São José Campestre. Nos mapas de 10 e 15 segundos (parte mais superficial da crosta) as anomalias de baixa velocidade foram relacionada às rochas sedimentares de Bacia do Potiguar.

\subsection{Objetivos}

O objetivo do trabalho é identificar as diferentes unidades geológicas da região de estudo e inferir sobre a evolução geológica do local, com respeito à sua distribuição de velocidades, utilizando-se os registros das estações sismográficas instaladas na região.

Os objetivos específicos são i) Analisar o comportamento das curvas de dispersão das ondas Rayleigh para diferentes contextos geológicos; ii) Gerar mapas de Velocidades de Grupo versus Período da onda superficial Rayleigh a partir de informações de ruído ambiental e eventos sísmicos; iii) Analisar os procedimentos de inversão que são aplicáveis para o contexto deste trabalho. 


\section{3 Área de Estudo e Contexto Geológico}

A Plataforma Sul-Americana (ALMEIDA, 1971) (Figura 1.1), que possui uma área de aproximadamente 15 milhões de $\mathrm{km}^{2}$, é entendida como a parte estável da América do Sul, com idades pré-cambrianas, e que não foi deformada pela Orogenia Andina. Ela pode ser dividida em três escudos: Escudo das Guianas (parte não imageada neste trabalho), Brasil Central e Atlântico, que são separados por bacias fanerozóicas (ALMEIDA, 1981). Na realidade, a Plataforma é formada pela junção de diversos blocos cratônicos, dentre eles: no Brasil encontram-se São Luiz, São Francisco, Amazônico, Paranapanema e Parnaíba; no Uruguai o Rio de al Plata; e na Argentina o Tandillia e o Sierras Australes. O território brasileiro se encontra totalmente compreendido por ela. O embasamento dela consiste em terrenos arqueanos e proterozóicos (blocos cratônicos) que foram circundados por cinturões móveis de diferentes idades ALMEIDA; NEVES; CARNEIRO, 2000).

A área de estudo deste trabalho compreende a parte leste da Plataforma Sul-Americana, abrangendo o Cráton do São Francisco (CSF), Bacia do Paraná, Faixa Brasília e as Províncias Mantiqueira e Borborema. O Cráton São Francisco localizado na porção centro-leste da Plataforma Sul-Americana, é uma região estável, que possui crosta com terrenos arqueanos e paleoproterozóico, e é delimitado pelos cinturões orogênicos neoproterozóicos do Brasiliano/Pan-Africano, como por exemplo Faixas Ribeira e Brasília (ALKMIM; CRUZ, 2005). A Faixa Brasília é um cinturão de dobras e cisalhamento neoproterozóico (VALERIANO et al., 1995). Ela apresenta terreno arqueano granitogreenstone na sua porção sul (HASUI et al., 2012).

A Bacia do Paraná é uma grande região com rochas sedimentares, aproximadamente 1,5 milhões de $\mathrm{km}^{2}$ de área, localizado na porção Sul do Brasil e está circundada por faixas neoproterozóicas e paleozóicas da orogenia Brasiliana/Pan-Africana ALMEIDA; NEVES; CARNEIRO, 2000). A partir de dados radiométricos foi proposta a existência de um Núcleo Cratônico (CORDANI, 1984), embora isto já sido havia sido sugerido anteriormente (FYFE; LEORNADO, 1974). Ele foi observado posteriormente em resultados geofísicos utilizando, principalmente, as técnicas de gravimetria (USSAMI, 1993), e tomografia sísmica de ondas de corpo (SCHIMMEL; ASSUMPÇAO; VANDECAR, 2003; ROCHA; SCHIMMEL; ASSUMPÇÃO, 2011), e de onda de superfície (FENG; ASSUMPÇAO; LEE, 2004; FENG; LEE; ASSUMPÇÃO, 2007). 


\subsection{Estações Sismográficas}

Para a utilização da metodologia deste trabalho é necessário densa cobertura de estações na área que se deseja estudar, para constituir vários caminhos interestações. Além disso, é necessário que estes caminhos se cruzem na região de interesse com azimutes diferentes, com o objetivo de melhorar a resolução das estruturas mapeadas. Desta forma, utilizouse estações sismográficas espalhadas pela porção leste e central do Brasil, as quais foram instaladas por meio de diferentes projetos ou por instituições de pesquisa do país (Figura 1.1). Entre as principais instituições de pesquisa que operaram as estações estão o Instituto de Astronomia, Geofísica e Ciências Atmosféricas da Universidade de São Paulo (IAG/USP), Universidade de Brasília (UnB), Universidade Federal do Rio Grande do Norte (UFRN) e o Observatório Nacional (ON). 


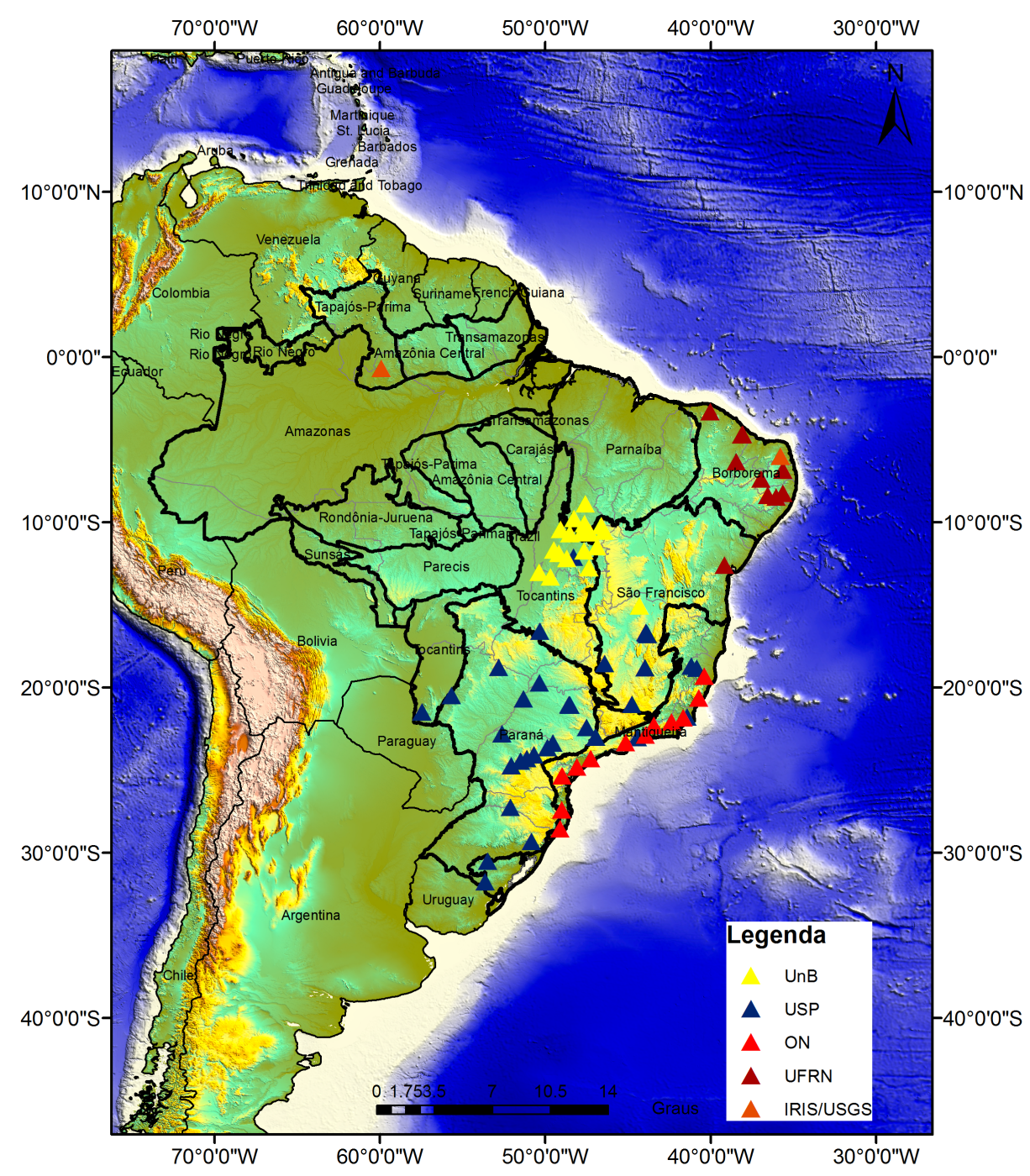

FigurA 1.1: Estações sismográficas representadas pelos triângulos, onde as cores indicam as instituições responsáveis pelas mesmas. Os contornos mais grossos representam as Províncias tectônicas do Brasil (BIZZI et al., 2003).

Os recursos utilizados para a instalação e manutenção das redes foram os mais diversos, desde pequenos projetos de pesquisas desenvolvidos por uma das instituições acima, até grandes projetos envolvendo diversas instituições. Dentre estes, destaca: a Rede Sismográfica Brasileira (RSBR) (BIANCHI et al., 2016), financiada pela Petrobras, a qual engloba quatro instituições, cada qual com a sua rede regional (USP - BL, UnB - BR, ON - ON, e UFRN - NB), cadastradas em um dos principais órgãos internacionais de sismologia (Incorporated Research Institutions for Seismology - IRIS). Foram utilizados também dados públicos de algumas estações das redes mundiais (redes GT, G e IU). 


\section{Capítulo 2}

\section{Revisão Bibliográfica}

\subsection{Caracterização das Ondas Sísmicas}

As ondas sísmicas podem ser caracterizadas de acordo com a forma de propagação sendo compressionais ou cisalhantes. Elas são agrupadas em duas classes de acordo com a interação com o ambiente: a primeira atravessa o meio pelo qual está se propagando e é conhecida como onda de corpo, e segunda que viaja ao longo da superfície e é conhecida como onda de superfície. As ondas de corpo podem ser divididas em duas, as do tipo P (primárias) que apresentam comportamento de compressão e dilatação ao se propagar, ou seja, faz as partículas se movimentarem longitudinalmente à direção de propagação, e as ondas S (secundárias), as quais apresentam o movimento da partícula perpendicular à direção de propagação da onda. Para a onda $\mathrm{S}$, o movimento pode ser dividido em duas componentes, onde a primeira está relacionada ao movimento vertical à direção de propagação (SV) e a segunda ao movimento horizontal (SH). O deslocamento (u) das ondas sísmicas que é descrito matematicamente como uma equação diferencial parcial $(\mathbf{u}=\nabla \phi+\nabla \times \psi)$ pode ser separado em soluções para as ondas $\mathrm{P}$ e S. Onde $\phi=\nabla \cdot \mathbf{u}$ e $\psi=\nabla \times \mathbf{u}$. Estas soluções são mostradas pelas Equações 2.1 (onda P), 2.2 (onda S), tal que $\alpha$ e $\beta$ (velocidades das ondas $\mathrm{P}$ e S) são combinações dos parâmetros de Lamé ( $\lambda$ e $\mu$ ) e densidade $(\rho),\left(\alpha=\sqrt{\frac{\lambda+2 \mu}{\rho}}\right.$ e $\beta=\sqrt{\frac{\mu}{\rho}}$ respectivamente) (SHEARER, 1999). A velocidade com que se propagam depende das propriedades elásticas do meio.

$$
\begin{aligned}
& \nabla^{2} \phi=\frac{1}{\alpha^{2}} \frac{\partial^{2} \phi}{\partial t^{2}} \\
& \nabla^{2} \psi=\frac{1}{\beta^{2}} \frac{\partial^{2} \psi}{\partial t^{2}}
\end{aligned}
$$


As ondas de superfície, por sua vez, são aquelas que se propagam na porção mais externa da Terra. Os tipos de ondas de superfícies são as Rayleigh (LR) e Love (LQ). As ondas Rayleigh são formadas pela combinação das ondas P e SV que se propagam simultaneamente ao longo do meio, gerando um movimento de partícula elíptico retrógrado próximo à superfície. As condições de contorno, necessárias para satisfazer a interação entre ondas $\mathrm{P}$ e SV implicam que estas ondas possuem velocidade inferior às ondas de cisalhamento $(\mathrm{S})$ e possuem decaimento $1 / r^{2}$ ( $r$ é a distância da fonte) de energia a partir da superfície. A propagação das ondas Rayleigh ocorrem com uma simetria cilíndrica, ou seja, uma simetria bidimensional, o que leva a amplitude dos diversos períodos que compõe o pacote de ondas serem proporcionais. Desta forma, essas ondas possuem o maior espectro de frequência em um registro de banda larga, quando comparado com as ondas de corpo, as quais o decaimento da amplitude é proporcional à $1 / r$ (LAY; WALLACE, 1995). As ondas Love são formadas pela interferência construtiva das ondas SH e suas respectivas múltiplas, o que leva o movimento da partícula ser horizontal, ou seja, na direção de propagação das ondas SH. As ondas Love apresentam decaimento exponencial da amplitude (LAY; WALLACE, 1995).

Em geral, o meio em que as ondas sísmicas se propagam apresentam um gradiente vertical de velocidade, visto que o mesmo é heterogêneo, o que implica que as ondas superficiais possuem velocidades diferentes para comprimentos de ondas distintos, o que é conhecido como Dispersão, vide Figura 2.1. Assim, períodos maiores trafegam com maior velocidade média, visto que estão a profundidades superiores.

Devido ao processo de dispersão, as ondas superficiais devem ser analisadas através das curvas de dispersão, nas quais relaciona-se a velocidade de tráfego ao comprimento de onda específico. Este procedimento pode ser realizado levando-se em conta tanto a velocidade de fase do pacote de onda, quanto a velocidade de grupo, que está relacionada ao envelope da onda. A relação entre os dois tipos de velocidade é dado pela equação 2.3 (LAY; WALLACE, 1995). A velocidade de grupo é um diferencial da velocidade de fase (velocidades de fase são maiores que as de grupo), sendo assim, pequenas variações em uma podem acarretar em grandes variações na outra, embora os dois tipos de velocidade apresentam a mesma informação. O comportamento da Terra, em geral, apresenta a diminuição das velocidades de fase com a frequência $\frac{d c}{d k}<0$ (STEIN; WYSESSION, 1991) logo as velocidades de grupo são sempre menores ou iguais às velocidades de fase. Neste trabalho serão feitas as análises das curvas de dispersão, apenas com as velocidades de grupo.

$$
U=\frac{d \omega}{d k}=\frac{d(k c)}{d k}=c+k \frac{d c}{d k}
$$



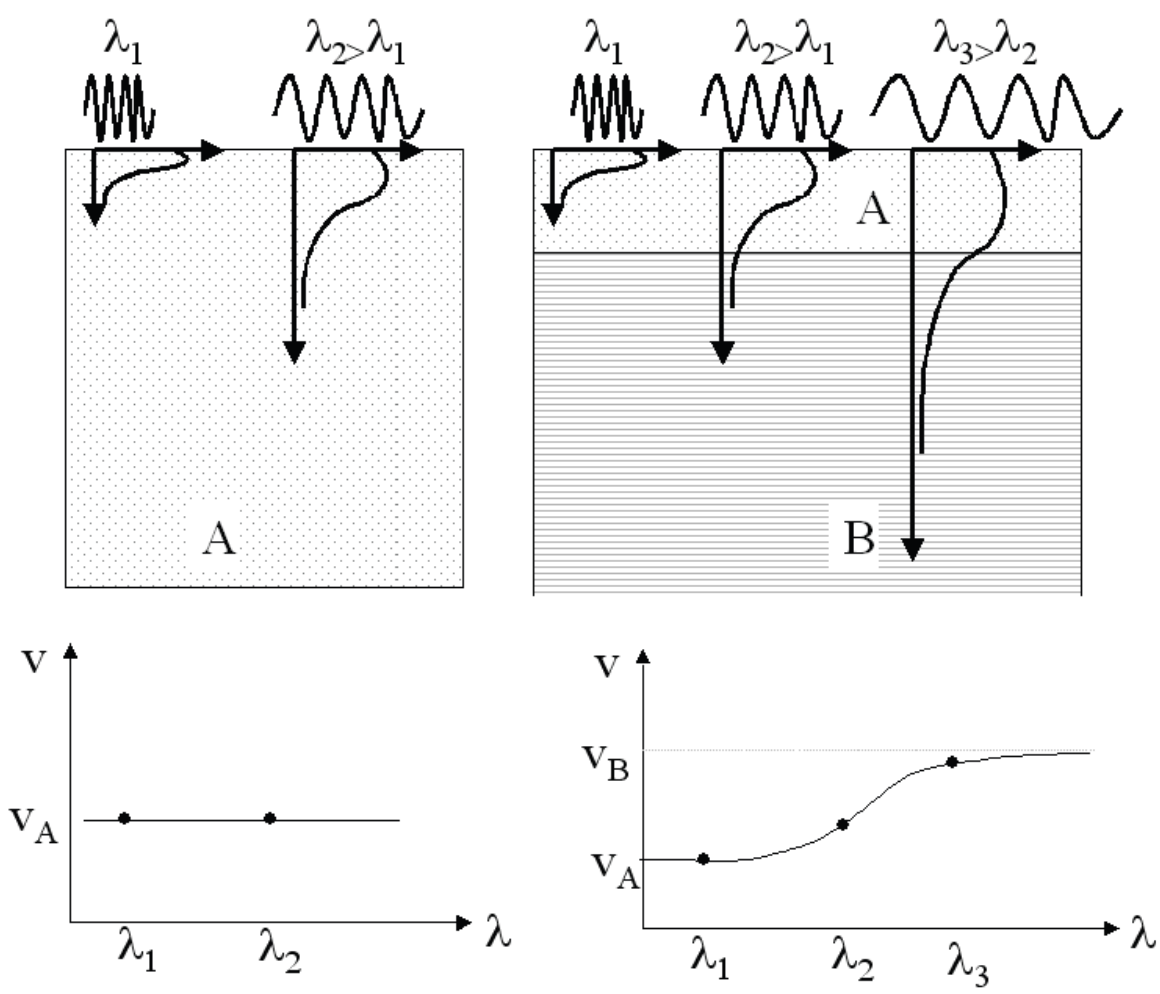

Figura 2.1: Dispersão de ondas superficiais. Em (A) apresenta-se as curvas em um meio homogêneo, ou seja, todos os comprimentos de onda amostram o mesmo material, portanto, a velocidade de grupo é constante. Quando as propriedades mudam com a profundidade, em (B), a velocidade depende do comprimento de onda, formando-se a curva de dispersão (Figura de Pei $(2007)$ ).

Onde $U$ representa a velocidade de grupo, $c$ é a velocidade de fase que depende da frequência $\omega$ e $k$ é o número de onda. A curva de dispersão, e a forma desta, depende do comportamento sísmico do meio pelo qual a onda se propaga. A Terra funciona como um filtro que atenua altas frequências (passa-baixa) devido a interação mais intensa destas com as partículas que compõe o meio, logo os comprimentos de ondas maiores atingem profundidades superiores para o harmônico respectivo. Desta forma, para um mesmo contexto geológico, cada harmônico pode possuir um comprimento de onda distinto, Aki e Richards (2002).

A sensibilidade é uma medida que é determinada pela derivada da velocidade de grupo com relação à velocidade da onda $\mathrm{S}$ (Equação 2.4), o que implica que, caso esta seja zero, não haverá mudanças na velocidade de grupo para diferenças na velocidade da onda S. No entanto, quanto mais afastados do zero estiverem, pequenas mudanças na velocidade de propagação da onda $\mathrm{S}$ gerarão significativas mudanças na velocidade de grupo da onda Rayleigh. Na Figura 2.2, verifica-se o comportamento de que, para menores períodos, a velocidade de grupo é mais afetada com mudanças na velocidade de 
propagação da onda $\mathrm{S}$, as quais refletem variações do meio. Também é observável que os períodos menores são sensíveis a profundidades menores.

$$
S=\frac{\partial U}{\partial \beta}
$$

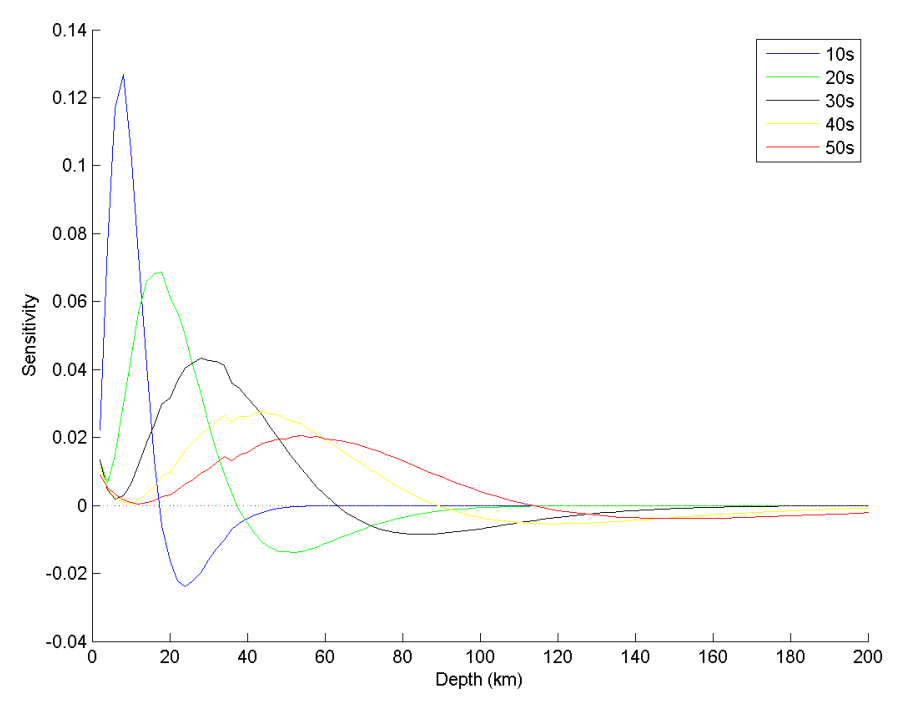

Figura 2.2: Sensibilidade de velocidade de grupo da onda Rayleigh para diferentes períodos, determinado com o modelo de velocidades IASP91.

\subsection{Caracterização do Ruído Ambiental}

O ruído sísmico pode ser definido como o conjunto de vibrações constantes na superfície da Terra, mesmo sem a ocorrência de terremotos, podendo ser considerado como oriundo de microfontes dispersas na superfície ou próximas a ela. O campo de ondas referente, é encontrado em todo o planeta e apresenta amplitudes pequenas, as quais só podem ser detectadas através de sensores construídos especialmente para tal tarefa, os quais abrangem uma banda larga de frequência. As amplitudes deste tipo de sinal encontramse na ordem de $10^{-4}$ a $10^{-2} \mathrm{~mm}$ e períodos entre 5 a 50 segundos (OKADA, 2003). Desta forma, o sinal recuperado a partir do ruído sísmico é análogo ao sinal gerado por microtremores ou microssismos (PEI, 2007).

Os estudos anteriores sobre os ruídos foram realizados para tentar decifrar sua natureza AKI, 1957, HORIKE, 1985), porém os sismólogos consideravam estes sinais como ruído aleatório que contaminava os registros sísmicos, e por isto não eram importantes e muitas vezes indesejados. Isso ocorreu até a utilização da técnica de correlação cruzada 
para a extração de sinais coerentes em Sismologia, não necessariamente gerados por uma fonte evidente (CLAERBOUT, 1968; SCHIMMEL, 1999, CAMPILLO; PAUL, 2003).

Foi demonstrado matematicamente e experimentalmente que uma estimativa da função do campo de ondas disperso, também conhecida como Função de Green, para a propagação entre um par de estações, poderia ser obtida através da correlação cruzada de registros simultâneos, livres de sinais oriundos de eventos.

A partir das características das Funções de Green determinadas, é possível obter informações sobre a propagação da onda entre o par de estações, por intermédio das curvas de dispersão resultantes, e, portanto, sobre as velocidades sísmicas da crosta e do manto superior ao longo do percurso (CAMPILLO; PAUL, 2003; BENSEN et al., 2007). Assim, a estrutura da Terra pode ser imageada a partir da análise do ruído sísmico.

As fontes que geram ondas sísmicas, consideradas como ruído ambiental, podem ser separadas em duas: as naturais e as artificiais (geradas pelo homem) (SHEARER, 1999). Para frequências baixas $(f<1 H z)$, a origem é primordialmente natural, e.g. geradas por ondas oceânicas, as quais possuem frequência máxima em torno de $0.2 \mathrm{~Hz}$. No entanto, para frequências altas $(f>1 H z)$, a origem é principalmente devido a atividade humana, (e.g. tráfego de veículos). No entanto, o ruído ambiental também pode ser causado pelo fluxo de fluídos (e.g. água, vento) (OKADA, 2003), como por exemplo os causados por tempestades. Na Tabela 1.1 apresenta-se um resumo do tipo de ruído, com a sua faixa de frequência, principais geradores do campo de ondas e as possíveis causas da variação de amplitude.

\begin{tabular}{|l|l|l|}
\hline & Natural & Artificial \\
\hline Nome & Microssismo & Microtremor \\
\hline Frequência & $\begin{array}{l}0.1 \mathrm{~Hz} \text { fnh }(0.5 \mathrm{~Hz} \mathrm{a} \mathrm{1} \\
\mathrm{Hz})\end{array}$ & $\begin{array}{l}\text { fnh }(0.5 \mathrm{~Hz} \text { a 1 Hz) - 10 } \\
\mathrm{Hz}\end{array}$ \\
\hline Origem & Oceanos & $\begin{array}{l}\text { Tráfego, Indústria, Ati- } \\
\text { vidade Humana }\end{array}$ \\
\hline $\begin{array}{l}\text { Tipo do campo de } \\
\text { onda }\end{array}$ & Ondas de Superfície & $\begin{array}{l}\text { Ondas de corpo e su- } \\
\text { perfície }\end{array}$ \\
\hline $\begin{array}{l}\text { Variação da Ampli- } \\
\text { tude }\end{array}$ & $\begin{array}{l}\text { Relacionado à tempes- } \\
\text { tades oceânicas }\end{array}$ & $\begin{array}{l}\text { Dia/Noite, Dias úteis/ } \\
\text { Fim de semana }\end{array}$ \\
\hline $\begin{array}{l}\text { Diferenciação dos } \\
\text { Harmônicos Funda- } \\
\text { mental / Superiores }\end{array}$ & $\begin{array}{l}\text { Principalmente furmônico } \\
\text { mental funda- }\end{array}$ & $\begin{array}{l}\text { Possibilidade } \\
\text { harmônicos superiores } \\
\text { para altas frequências } \\
\text { (caso seja uma situação } \\
\text { de pelo menos duas } \\
\text { camadas) }\end{array}$ \\
\hline
\end{tabular}

TABela 2.1: Resumo das características do ambiente de ruído (modificado de (PEI, 2007)). Na tabela fnh é a frequência limite entre Natural e Artificial. 


\subsection{Função de Green}

A Função de Green é chamada desta forma em homenagem ao matemático e físico inglês George Green (1793 - 1841). Ela define o efeito que uma fonte pontual gera no meio e ao seu redor. Assim, o deslocamento pontual de uma fonte é resultado da resposta do meio convolvido pelo tensor de força sobre área, por um período de tempo para se determinar o resultado do meio. Neste trabalho este é considerado como o espaço entre o par de estações, e como um todo integra-se pelos limites considerados, conforme é mostrado na Equação 2.5.

A Função de Green é a solução de quaisquer equações diferenciais não homogêneas com fontes pontuais. Para a Sismologia ela é a solução indireta da equação diferencial de movimento (Equação 2.6). A determinação desta função permite descrever como será a resposta do meio dado uma fonte qualquer, uma vez que se conheça a assinatura da fonte. Portanto, a recuperação da função de Green representa a caracterização do movimento do meio.

Ela apresenta a característica de reciprocidade e pode ser obtida pelo processo de correlação cruzada dos sinais simultâneos entre um par de estações, simulando uma das estações como fonte e a outra como receptor. A função de correlação $\left(C_{i j}\left(x_{a}, x_{b}, t\right)\right)$ é relacionada com a função de Green $\left(G\left(x_{a}, x_{b}, t\right)\right)$ no domínio do tempo pela Equação 2.7.

No entanto, para que a recuperação da onda Rayleigh ocorra a partir de um ambiente de ruído é necessário empilhar vários registros do mesmo caminho para que se possa atenuar o ruído aleatório e recuperar a forma da onda desejada.

$$
\begin{gathered}
\mathbf{u}_{n}(\xi, \tau)=\int_{-\infty}^{\tau} d t \iiint_{V} f_{i}(\mathbf{x}, t) G_{n}(\mathbf{x}, t) d V \\
\rho \frac{\partial^{2} \mathbf{u}}{\partial t^{2}}=(\lambda+2 \mu) \nabla(\nabla \cdot \mathbf{u})-\mu(\nabla \times \nabla \times \mathbf{u}) \\
\frac{\partial C_{i j}\left(x_{a}, x_{b}, t\right)}{\partial t} \approx-G\left(x_{a}, x_{b}, t\right)+G\left(x_{a}, x_{b},-t\right)
\end{gathered}
$$

Na Figura 2.3 (a) é apresentado um modelo simplificado de um campo de onda referente ao ruído ambiental, o qual apresenta a propagação de ondas planas. As Figuras 2.3 (b) e (c) apresentam as respostas do meio nas estações $X_{A}$ e $X_{B}$ geradas pelas fontes em $X_{S}$ e $X_{S}^{\prime}$, respectivamente. Em (d) tem-se o resultado das funções de correlação cruzada das séries temporais das estações $X_{A}$ e $X_{B}$. Além disso, elas apresentam um comportamento simétrico com relação ao zero do resultado da correlação, o que é esperado, pois a parte positiva denota o caminho $X_{A}$ para $X_{B}$, e a negativa o caminho 
contrário. Como o registro da resposta do meio entre a fonte e a estação é idêntico para um par de estação, no processo de correlação esta parte do registro será zero, logo a localização da fonte é irrelevante para este método.
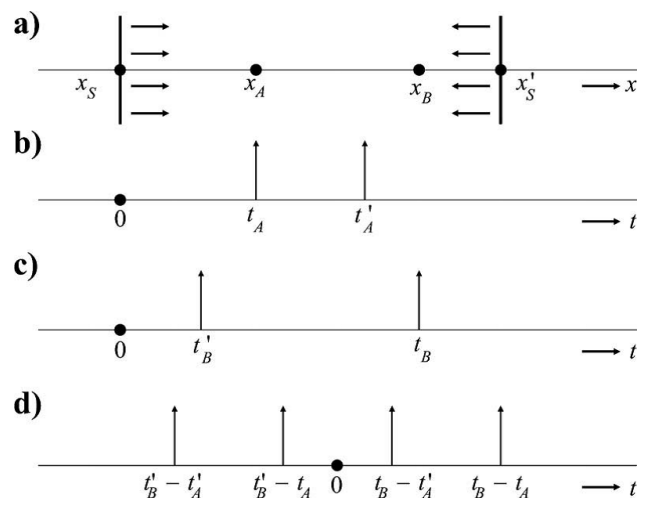

Figura 2.3: Em (a) apresenta-se um campo de ondas do ruído simplificado com ondas planas e duas estações $\left(X_{A}\right.$ e $\left.X_{B}\right)$. Em (b) mostra-se a resposta da estação $X_{A}$ à passagem das ondas. Em (c) mostra-se a resposta da estação $X_{B}$. Em (d) mostra-se a resposta da correlação dos respectivos registros das estações (Figura de Wapenaar et al. (2010)).

\subsection{Inversão}

Os problemas inversos estão relacionados a várias áreas da ciência, como a física, geofísica, matemática e engenharia. A teoria deste campo foi desenvolvida nas últimas décadas devido à sua aplicabilidade. No entanto, foi com o desenvolvimento da computação e de metodologias numéricas que possibilitou-se a utilização deste processo (ZHDANOV, 2002).

O problema inverso consiste em se obter a partir de dados coletados (observações), os parâmetros que caracterizam o modelo da região estudada. Ou seja, o objetivo é minimizar a diferença entre os dados e resultados modelos gerados com relação a diferentes normas. Geralmente este problema é dito mal-posto, pois a solução pode não existir ou não possuir unicidade, ou seja, existem vários modelos que ajustam o conjunto de dados de forma significativa (HADAMARD, 2014). Além disso, o problema é mal condicionado, ou seja, pequenas variações no conjunto de dados geram significativas mudanças no modelo. Devido a isso, a regularização (informação a priori) deve ser incluída, embora haja ambiguidade na sua escolha (SCALES; SNEIDER, 1997). Assim, o resultado obtido aproxima a realidade dentro da escolha dos parâmetros da estimativa de erro inerente ao processo. O modelo obtido pode diferir do real devido a não unicidade da solução ou devido erros nos dados de entrada. 
O problema pode ser descrito matematicamente como linear ou não-linear, modificandose o tipo de equações que governam o sistema. O problema inverso da tomografia de ruído ambiental para obter feições estruturais é um problema não linear, logo para resolve-lo são necessárias duas etapas de inversão. Na primeira obtêm-se modelos de velocidade de grupo ou fase em função da frequência. A partir desta solução inverte-se para obtenção do modelo de profundidade. Isso é possível, pois há uma relação da velocidade do meio em função da frequência e a pertubação do meio em função da profundidade, vide Equação 2.8. Desta forma, reduz-se o problema não linear em dois problemas lineares (SNIEDER; TRAMPERT, 1999). A Equação 2.9 representa um sistema linear.

$$
\frac{\delta c}{c}=\int K_{\beta}(z) \frac{\delta \beta(z)}{\beta(z)} d z+\int K_{\alpha}(z) \frac{\delta \alpha(z)}{\alpha(z)} d z+\int K_{\rho}(z) \frac{\delta \rho(z)}{\rho(z)} d z
$$

Na Equação 2.8, as funções $K_{\alpha}, K_{\beta}$ e $K_{\rho}$ são referentes as funções de Kernel que caracterizam as ondas $\mathrm{P}, \mathrm{S}$ e densidade do meio respectivamente. Um exemplo desta função, $K_{\beta}$, para as ondas Rayleigh em diferentes períodos no seu modo fundamental é apresentado na Figura 2.2 .

$$
G \mathbf{m}=\mathbf{d}
$$

A matriz $G$ representa a relação entre os parâmetros do modelo $m(x)$ e os dados coletados $d(x)$, que neste trabalho são os tempos de trânsito da onda Rayleigh. O sistema de matriz no domínio discreto é construído seguindo a Equação 2.10.

$$
d_{i}=\sum_{j=1}^{N} G_{i j} m_{j}
$$

O tempo de trânsito (Equação 2.11) entre o ponto de origem da onda e a estação receptora (quando se trata da ANT considera-se o tempo de trânsito como o tempo necessário para percorrer a distância entre o par de estações) pode ser definido como:

$$
\begin{gathered}
t(s)=\int_{L} s(x) d l=\int_{L} \frac{1}{v(x)} d l \\
t(s)=\sum_{i=1}^{n} s_{i}(x) d_{i}
\end{gathered}
$$

Os mapas de velocidade $c(\mathbf{r}$ ) (grupo ou fase) são obtidos a partir de um conjunto de tempos de trânsito observados $\left(t_{o b s}(\omega)\right)$ para vários caminhos $p$ em uma frequência $\omega$ específica. Este pode ser descrito pela Equação 2.13 onde $\epsilon$ representa o erro de 
observação para o caminho em analise. O problema é linear se os caminhos pelo qual a onda trafega são conhecidos. O princípio de Fermat diz que o tempo de trânsito de um raio é "estacionário" com respeito a pequenas mudanças com relação ao mesmo. Assim, o caminho da onda se aproxima a um modelo esférico, o que representa um grande círculo ligando o par de estação (ou fonte e receptor). Essa aproximação é válida quando o meio possui heterogeneidade lateral que produz desvios no caminho menores do que a resolução do mapa de velocidades (BARMIN; RITZWOLLER; LEVSHIN, 2001).

$$
t_{o b s}(\omega)=t(\omega)+\epsilon(\omega)
$$

O processo de inversão dos tempos de percurso das ondas Rayleigh para a sua velocidade de grupo pode ser descrito como um sistema de equações lineares, de forma que para cada caminho o tempo de percurso é expresso pela Equação 2.12, tal que $t$ é o valor encontrado a partir da análise da curva dispersão, d é a distância entre o par de estações e $s$ é a vagarosidade $(1 / v)$, a qual é função da profundidade, $s(z)$. Para se determinar a velocidade de grupo do sistema, define-se a região a ser estudada, a qual é parametrizada em uma malha de células, em nosso caso regular, na qual cada uma possui um valor de vagarosidade. Desta forma, o tempo de percurso entre duas estações pode ser escrito como a soma dos tempos parciais de cada célula que as separam.

A regularização trata dos vínculos matemáticos/geológicos para que o resultado da inversão possua uma característica geológica plausível e não apenas uma solução numérica. Neste trabalho os vínculos são funções de penalidade que minimizam os efeitos de grandes valores de normas dentro da inversão, conhecido como suavidade. A escolha deste parâmetro é específica para cada problema, pois ele varia de acordo com a escala de trabalho (local ou regional), com o ambiente geológico onde se esta trabalhando e com a quantidade e qualidade do dado que é utilizado.

A parametrização na tomografia de ondas de superfície pode ser realizada com integrais de kernel (BACKUS; GILBERT, 1967), ajuste de função, blocos e nós.

O modelo de nós é definido como um número discreto de pontos ao longo de uma região espacial onde cada um deles possui uma amplitude (neste caso é o valor da velocidade da onda) os valores na região entre os nós é definida com um algoritmo de interpolação. A escolha de utilizar os nós é que eles permitem uma maior generalização do modelo.

Os parâmetros utilizados na inversão são bastante variáveis. O sistema de coordenadas utilizado para definir o espaço no código de inversão é o esférico, pois este considera a curvatura terrestre o que não ocorre para o sistema de coordenadas plano. 
Para resolver o problema direto é necessário criar um espaço matemático que discretize a região que está sendo estudada. Isto pode ser feito com a construção de nós espaçados a distância constante, sendo e a região entre eles interpolada utilizando "nearest neighbors". Nesta região, que representa a malha de células para a solução, é resolvido o problema direto e o inverso.

Os raios (percurso pelo qual a onda tráfega) foram considerados como amostras infinitesimais ao longo de um grande círculo que liga a fonte e o receptor, no entanto o espalhamento que ocorre no caminho não é considerado no código utilizado (PASYANOS, 2005).

Utiliza-se de um modelo de velocidade global para se resolver o problema direto para a malha determinada, gerando-se um conjunto de tempos teóricos que serão subtraídos dos tempos observados para se determinar o residual relativo, pois este é o vetor de entrada do algoritmo de inversão.

O objetivo do problema inverso é encontrar o vetor $\mathbf{m}$ para o conjunto de tempos residuais (Equação 2.14) relativos a um modelo de referência. Logo para estimá-lo deve-se minimizar o sistema linear (Equação 2.9) e as funções de penalidade que foram descritas antes.

$$
d=\delta t_{o b s}=t_{o b s}-t_{m}=\int_{p} \frac{m}{c_{0}} d s+\epsilon
$$

A equação 2.15 representa a função objetivo a ser minimizada, onde a função $F_{k}$ representa a suavidade espacial para o modelo, e a constante $\alpha_{k}$ é a amplitude desta correção é parâmetro escolhido pelo usuário de forma empírica. Similarmente à função $H_{k}$ representa os pesos espaciais de cada curva com o parâmetro $\beta_{k}$ sendo a sua amplitude. Esta forma de parametrização pode ser omitida pelo usuário, pois ela foi definida automaticamente no código utilizado (PASYANOS, 2005).

$$
(\mathbf{G}(\mathbf{m})-\mathbf{d})^{T} \mathbf{C}^{-1}(\mathbf{G}(\mathbf{m})-\mathbf{d})+\sum_{k=0}^{n} \alpha_{k}^{2}\left\|F_{k}(\mathbf{m})\right\|^{2}+\sum_{k=0}^{n} \beta_{k}^{2}\left\|H_{k}(\mathbf{m})\right\|^{2}
$$

Existe vários métodos para a resolução do problema inverso. Pode-se se dividi-los em três categorias:

- Determinísticos: Método de Newton, Gradiente Conjugado, Levenberg-Marquadt;

- Estocásticos: Algoritmo genético, Otimização Extrema; 
- Híbridos: combina as duas categorias anteriores.

Para resolvermos a inversão neste trabalho utilizamos o método conhecido como gradiente conjugado. Esta metodologia é adequada para resolver problemas com matrizes esparsas do sistema linear em questão.

Esta metodologia minimiza a função objetivo, ou seja, ela procura o ponto de mínimo da função. O algoritmo toma um ponto como estimativa inicial $x_{0}$, para que o algoritmo comece a trabalhar (Equação 2.16). No entanto, por ser um método determinístico ele não distingue mínimos locais do global o que pode levar a resultados enganosos, especialmente para casos não lineares.

$$
d_{0}=r_{0}=d-G m_{i}
$$

Utilizando-se a técnica de "passo descendente," a qual busca a direção de decrescimento máximo, ou seja, a de maior gradiente (negativo) $\frac{-\partial \phi}{\partial x_{i}}=d-G m_{i}$ para escolher a direção (Equação 2.17) que o próximo ponto que a segunda iteração irá buscar, onde $\alpha_{i}$ é o passo.

$$
\alpha_{i}=\frac{r_{i}^{T} r_{i}}{d_{i}^{T} G d_{i}}
$$

A partir da direção calculada determina-se o próximo ponto (Equação 2.18) e o processo se repete pelo número de iterações que foi definido pelo usuário. Ao final, se o processo convergir a solução será encontrada.

$$
\begin{gathered}
x_{i+1}=x_{i}+\alpha_{i} d_{i} \\
\beta_{i+1}=\frac{r_{i+1}^{T} r_{i+1}}{r_{i}^{T} r_{i}} \\
d_{i+1}=r_{i+1}+\beta_{i+1} d i
\end{gathered}
$$




\section{Capítulo 3}

\section{Metodologia}

\subsection{Introdução}

O ruído ambiental é composto de um campo de ondas difuso com amplitudes e fases aleatórios que se propagam em todas as direções. Consequentemente ele contêm informações sobre todos os possíveis caminhos que podem ser extraídos através da correlação entre pares de estações.

Algumas das limitações para extrair as ondas Rayleigh do ruído ambiental são: retirar informações de eventos, pois este possuem amplitudes muito grandes quando comparado com o ruído ambiental. O ANT é efetivo até 40s. O método somente é eficiente se utilizado com uma densa rede sismográfica ativa concomitantemente, pois é necessário que haja vários cruzamentos entre os pares de estações de diversos azimutes distintos. Também se faz necessária a retirada da resposta dos instrumentos.

Para determinar o número de dias necessários para recuperar as ondas dispersas, selecionou-se os pares de estações com o maior número de dias com coletas de dados simultâneos, possuindo pelo menos 365 dias, o resultado do empilhamento destes pares foi considerado como o resultado ótimo para aquele par. A partir disso, fez-se o empilhamento de cada dia com todos aqueles anteriores a este e calculou a correlação cruzada deste empilhamento com o resultado ótimo (Figura 3.1, onde $R$ representa o coeficiente de correlação). Nota-se que com 60 dias já é possível começar a obter resultados com os dados da rede conforme a Figura 3.1, recuperação com índice de correlação maior que 0.9 do resultado ótimo. Os pontos pretos no gráfico representam os empilhamentos para diferentes números de dias apresentados na Figura 3.4

Os procedimentos utilizados no processamento da ANT foram similares aos de Bensen et al. (2007). Foi utilizada apenas a componente vertical do ruído ambiental o que 


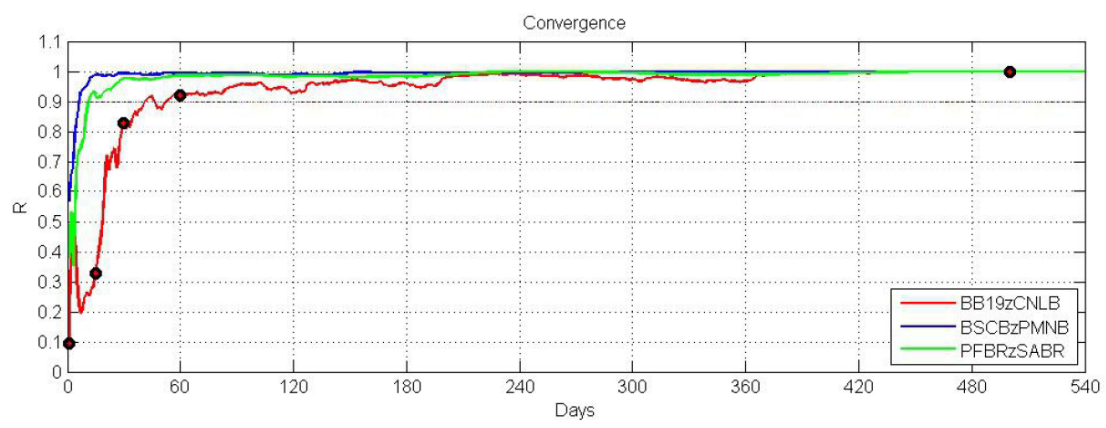

Figura 3.1: Convergência das curvas de dispersão pelo número de dias empilhados. Os pontos pretos indicam o número de dias empilhados que foram utilizados para a obtenção da forma de onda (vide Figura 3.4).

implica que a correlação cruzada recuperam apenas sinais de onda Rayleigh. O processamento pode ser dividido em quatro fases principais 1) Organização da base de dados, 2) Correlação cruzada e empilhamento, 3) Medidas das curvas de dispersão (realizadas no domínio da frequência com a análise de fase), e 4) Controle de qualidade com inclusão da analise de erro e seleção de medidas aceitáveis e 5) Inversão dos dados (Figura 3.2.

Etapa 1: Organização da base de dados

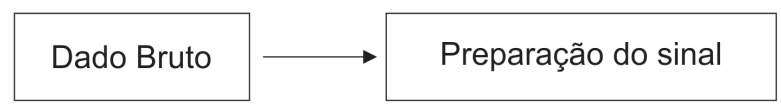

\section{Etapa 2: Correlação cruzada e empilhamento}

\begin{tabular}{|c|}
\hline $\begin{array}{c}\text { Cálculo da correlação } \\
\text { cruzada }\end{array} \longrightarrow$\begin{tabular}{c|} 
Empilhamento diário das \\
correlações cruzadas
\end{tabular} \\
\hline
\end{tabular}

\section{Etapa 3: Medidas das curvas de dispersão}

Medida das Velocidades

de grupo/fase

\section{Etapa 4: Controle de qualidade}

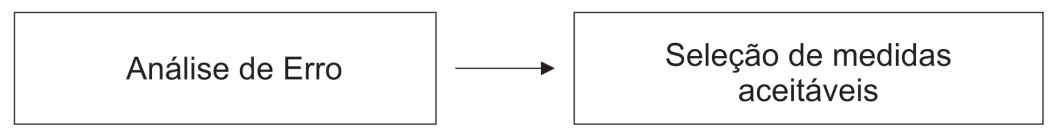

Etapa 5: Inversão dos dados

Inversão

Figura 3.2: Etapas de processamento dos dados para gerar a ANT (Figura modificada de Bensen et al. (2007)). 


\subsection{Organização da base de dados}

\subsubsection{Dados Brutos}

Os dados que serão utilizados são registros sísmicos obtidos de estações sismográficas de banda larga com três componentes, porém só será utilizado a componente vertical. Como trabalhou-se com estações sismográficas de diferentes fabricantes, cada uma delas possui uma formatação para o armazenamento de seus registros, sendo necessário transformar todos os registros para uma única formatação. Para isso foi escolhido o formato miniSEED, que é um subconjunto do formato SEED (Standart for the Exchange of Earthquake Data), na qual a sua formatação é ideal para armazenar e transferir arquivos, e além disso, os pacotes de análise de dados sísmicos (e.g. SeisComp) utilizam este formato em seus bancos de dados. As formas de onda são armazenadas em arquivos, os quais contêm, a série temporal. Enquanto o histórico da estação e suas informações do seu meta-dado estão compreendidas em arquivos separados (dataless). Os dados são armazenados em formato 24 horas (00:00:00 - 23:59:59), com a separação das componentes Vertical, Norte-Sul e Leste-Oeste.

\subsubsection{Preparação do Sinal}

A preparação dos dados envolve todos os passos que tratam da remoção de sinais não desejados para a aplicação da metodologia escolhida como a remoção dos eventos (terremotos), resposta do instrumento visando retirar a influência do instrumento, restando a resposta do meio. Esses passos estão sumarizados na Etapa 1 da Figura 3.2 .

\subsection{Correlação cruzada e empilhamento}

\subsubsection{Cálculo da correlação cruzada}

O processo de correlação cruzada dos dados foi feito utilizando-se o intervalo de lag-time de -450 a 450 s. Escolheu-se utilizar a correlação cruzada de fase (PCC) (SCHIMMEL, 1999), pois ela não apresenta dependência da amplitude do sinal (ao contrário da correlação cruzada convencional (CCGN), Equação 3.2), visto que ela utiliza a análise complexa do traço e é baseada na similaridade das fases instantâneas do mesmo, (Equação 3.1), o que implica em um sinal com menor quantidade de ruído e apresenta melhor recuperação do sinal desejado. Isto pode ser visualizado na Figura 3.3 , que mostra o resultado dos dois tipos de correlação para uma mesma série temporal, e fica claro que a PCC apresenta melhor resultado para a recuperação de ondas de baixa amplitude. 


$$
\begin{gathered}
C_{P C C}(\tau)=\frac{1}{2 N} \sum_{\tau=\tau_{0}}^{\tau_{0}+T}\left[\left|e^{i \phi(t+\tau)}+e^{i \phi(\tau)}\right|-\left|e^{i \phi(t+\tau)}-e^{i \phi(\tau)}\right|\right] \\
C_{C C G N}(\tau)=\frac{\sum_{\tau=\tau_{0}}^{\tau_{0}+T} s_{1}(t+\tau) s_{2}(\tau)}{\sqrt{\sum_{\tau=\tau_{0}}^{\tau_{0}+T} s_{1}(t+\tau)^{2} \sum_{\tau=\tau_{0}}^{\tau_{0}+T} s_{2}(\tau)^{2}}}
\end{gathered}
$$
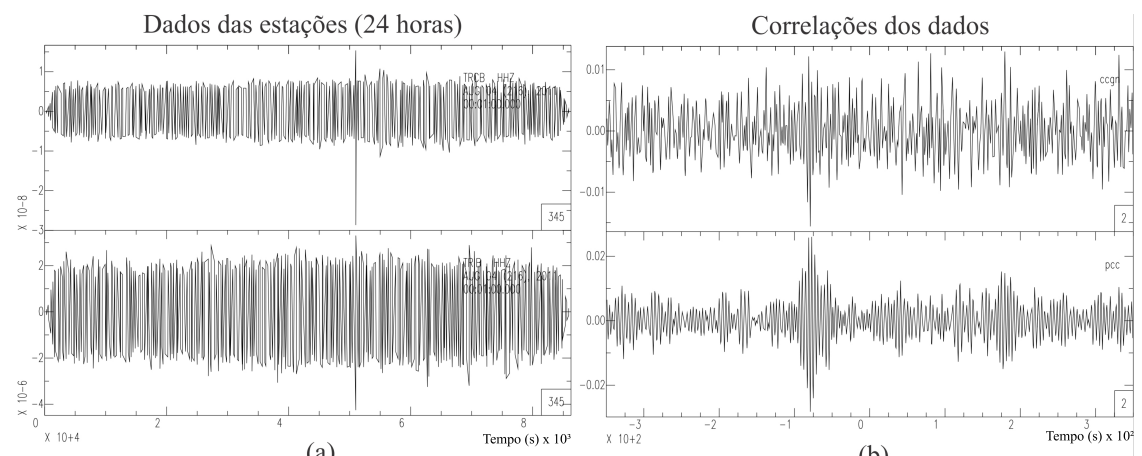

(a)

(b)

Figura 3.3: Em (a) tem-se o registro 24 horas das estações TRCB e TRIB na componente vertical do dia 4/08/2011. Em (b) tem-se o resultado da correlação cruzada destes dados utilizando-se os algoritmos de correlação CCGN (superior) e PCC (inferior)

\subsubsection{Empilhamento diário das correlações cruzadas}

Utilizou-se o empilhamento das correlações cruzadas diárias para realçar a recuperação do sinal e aumentar a razão sinal/ruído a técnica utilizada foi a tf-PWS (time-frequency phase weighted stacking) desenvolvida por Schimmel (2007) no qual é uma extensão do algoritmo PWS de Schimmel (1999) onde cada amostra de um empilhamento linear é ponderada por uma medida de coerência que é independente da amplitude. Os pesos da PWS são expressos pela Equação 3.3 , onde $c(t)$ é o empilhamento de fase do sinal analítico, $N$ o número de traços, $j$, é o índice contador e $\phi(t)$ é a fase instantânea e $\nu$ é a potência do operador que ajusta a transição entre o sinal coerente e incoerente, foi usado o valor de 2, segundo o trabalho de Schimmel e Paulssen (1997) ajuste entre sinais coerentes.

O empilhamento tf-PWS pode ser descrito pela Equação 3.4 onde $S_{j}(\tau, f)$ é a transformada S (STOCKWELL; MANSINHA; LOWE, 1996) da série de tempo $j$ e a $S_{1 s}(\tau, f)$ é a transformada $\mathrm{S}$ do empilhamento linear de todas as $N$ séries temporais e a função $c_{t} f(\tau, f)$ é utilizada para ponderar os sinais incoerentes. Um exemplo do resultado do processo de empilhamento é mostrado na Figura 3.4. onde cada sismograma mostrado 
é o resultado do empilhamento de diferentes quantidades de dias correlacionados (canto inferior direito). Nota-se que poucos dias são necessários para um sinal coerente surgir.

$$
\begin{gathered}
c(t)=\frac{1}{N}\left|\sum_{j=1}^{N} e^{i \phi_{j}(t)}\right|^{\nu} \\
p_{t f}(\tau, f)=S_{1 s}(\tau, f) c_{t f}(\tau, f)=S_{1 s}(\tau, f)\left|\frac{1}{N} \sum_{j=1}^{N} \frac{S_{j}(\tau, f) e^{i \pi f \tau}}{S_{j}(\tau, f)}\right|^{\nu}
\end{gathered}
$$

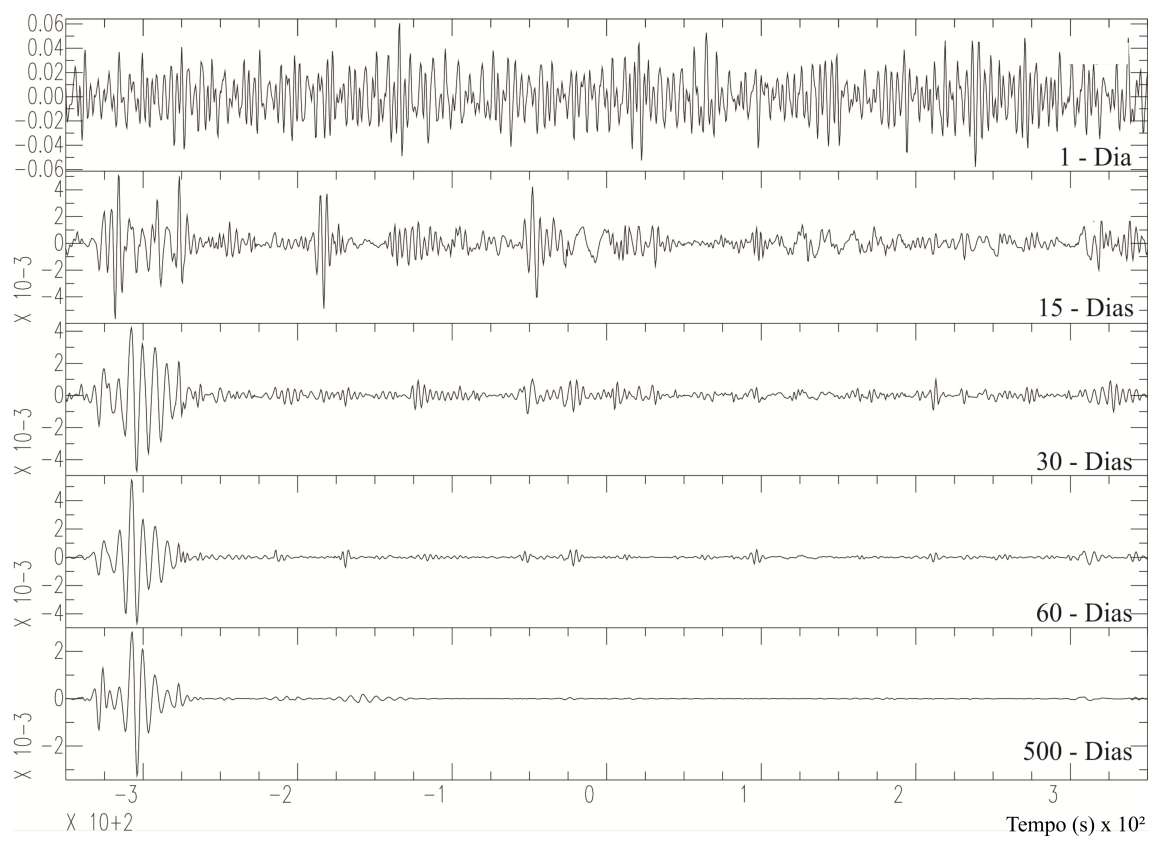

FigurA 3.4: Resultado do processo de empilhamento das correlações diárias entre as estações BSCB e PMNB.

\subsection{Medida das curvas de dispersão}

\subsubsection{Medida da Velocidade de Grupo}

A partir da estimativa da função de Green realizada pelo empilhamento das correlações cruzadas é possível obter as velocidades de fase e grupo como função do período, que podem ser encontradas através da análise de tempo-frequência (DZIEWONSKI; BLOCH; LANDISMAN, 1969; YANOVSKAYA et al., 2012; RITZWOLLER; LEVSHIN, 1998). O método de análise das curvas escolhido nesse trabalho obtêm as formas de ondas para as curvas utilizado várias iterações de análise, embora seja computacionalmente mais 
exigente, do que a análise manual de cada curva de dispersão, essa metodologia permite automação, o que permite processar grandes bancos de dados de forma mais eficiente.

Para uma forma de onda $s(t)$ que tem a transformada de Fourier definida com o expoente positivo $S(\omega)=\int_{-\infty}^{\infty} s(t) e^{i \omega t} d t$ a medida da dispersão é o sinal analítico que é definido no domínio da frequência (Equação 3.5). Para construir a função frequênciatempo o sinal analítico é submetido a um filtro gaussiano (Equação 3.7) passa-banda "estreito "com a frequência central em $\omega_{0}$.

$$
\begin{gathered}
S_{a}(\omega)=S(\omega)(1+\operatorname{sgn}(\omega)) \\
S_{a}\left(\omega, \omega_{0}\right)=S(\omega)(1+\operatorname{sgn}(\omega)) G\left(\omega-\omega_{0}\right) \\
G\left(\omega-\omega_{0}\right)=e^{-\alpha\left(\frac{\omega-\omega_{0}}{\omega_{0}}\right)^{2}}
\end{gathered}
$$

Ao passar a transformada de Fourier inversa para cada função filtrada com o filtro passa banda obtêm-se a função envelope 2-D $\left(\left|A\left(t, \omega_{0}\right)\right|\right)$ e a função de fase, $\phi\left(t, \omega_{0}\right)$ sendo que a velocidade de grupo é retirada da primeira e a de fase da segunda, selecionando-se os picos das funções respectivas para a frequência $\omega_{0}$.

\subsection{Controle de Qualidade}

\subsubsection{Correção de Erros e seleção de medidas aceitáveis}

Uma medida aceitável de velocidade para uma curva de dispersão, e para um período $\tau$, requer uma distância entre estações $(\Delta)$ de pelo menos três comprimento de onda $(\lambda)$. A partir disso obtêm-se que o máximo período alcançado para uma distância de estações é dado por $\tau_{\max }=\Delta / 12$ (BENSEN et al., 2007). Foi aplicado um extenso sistema de controle de qualidade para tentar produzir um modelo com as melhores curvas possíveis dentro do banco de dados.

O controle de qualidade foi aplicado em três estágios: O primeiro foi o corte dos dados a partir do resíduo, o que consiste em calcular o tempo de trânsito teórico para cada caminho e comparar com o tempo medido. Se ele estiver dentro do intervalo de corte escolhido o caminho é mantido, se não é descartado. O intervalo escolhido foi de $[-30,30]$ (s). Posteriormente foi aplicado um corte de velocidade para aquele período, os valores das velocidades escolhidas foram baseadas em modelos globais. A Figura 3.5 mostra para o período de $10 \mathrm{~s}$ o corte aplicado aos dados. Apenas os pontos (caminhos) 
que estão entre os dois limites das abcissas e os dois da ordenada são os que foram utilizados no processo de inversão. Finalmente, o último critério de corte foi com base na razão sinal ruído (SNR) do dado. Foram realizados vários testes de corte e o limite escolhido foi $S N R>25$.

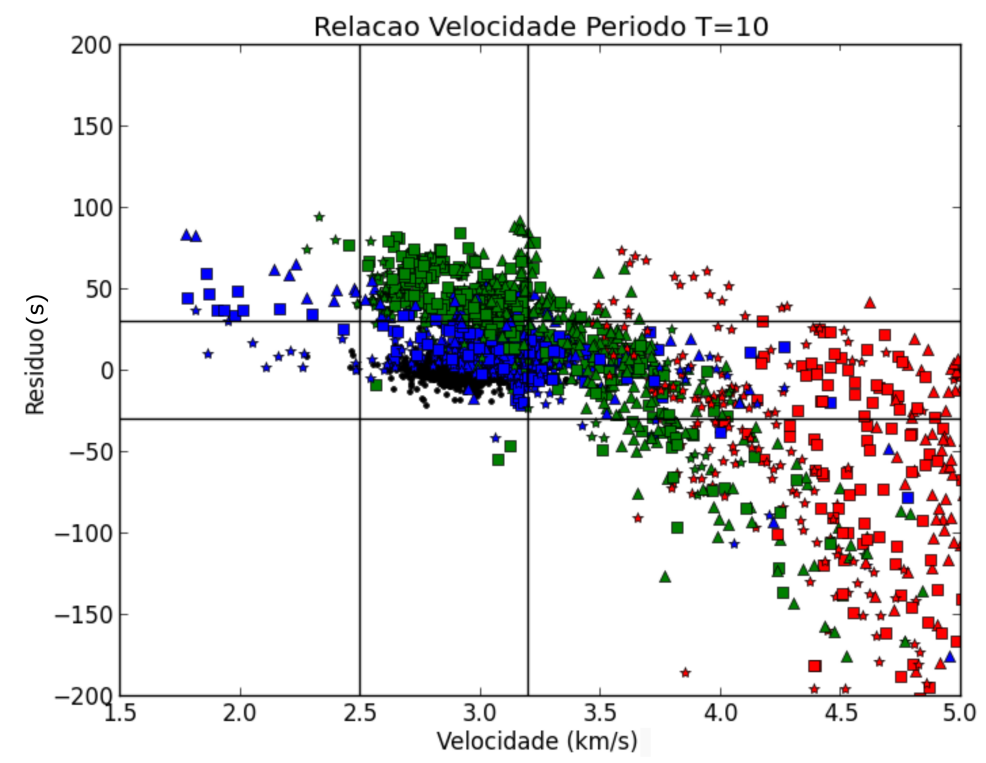

Figura 3.5: Corte de dados que não satisfazem o controle de dados definido. As cores representam a distância entre pares de estações: preto $<150 \mathrm{~km}$, azul $(150,500] \mathrm{km}$, verde $(500,750] \mathrm{km}$ e vermelho $>750 \mathrm{~km}$.

\subsection{Inversão dos dados}

\subsubsection{Inversão}

Para a obtenção dos mapas de velocidade de grupo utilizou-se do método proposto por Pasyanos (2005). A região de estudo foi dividida em células de igual área segundo o sistema de Equações 2.12 e 3.8 , onde o último impõe uma sistema de amortização no modelo de parâmetros ao construir os operadores Laplacianos bidimensionais $(\mathbf{L})$ para a vagarosidade. $\mathrm{O}$ fator de suavidade $(\lambda)$ controla a troca entre o ajuste dos tempos de trânsito e a suavização do modelo. Este tipo de inversão não depende significamente do modelo inicial de velocidades. O processo de inversão foi aplicado duas vezes, a primeira utilizando o modelo global IASP91 de entrada e a segunda utilizando o resultado da primeira inversão como modelo de entrada.

$\lambda \mathbf{L s}=0$ 
A resolução dos mapa de velocidade de grupo é uma função da densidade de caminhos, da distribuição azimutal e do tamanho dos caminhos utilizados. O tamanho das células utilizadas foi de $1^{\circ}$. Vários testes foram realizados para a escolha da suavidade (Figura 3.6. Outros fatores além destes citados dificultam a obtenção de um modelo real, tais como a distorção do campo de ondas devido a não homogeneidade lateral, erros na localização de estações e anisotropia do meio (VDOVIN et al., 1999).

Algumas simplificações foram feitas para realizar a tomografia como desconsiderar o efeito da anisotropia, os desvios da trajetória (considerando uma linha reta entre as estações). A investigação sobre a validade da aproximação da trajetória levando em conta que a primeira zona de Fresnel seja menor do que o tamanho da heterogeneidade (LEVSHIN et al., 2005) não foi verificada.

A escolha dos parâmetros foi feita para evidenciar o melhor resultado com os dados disponíveis. As células tem espaçamento de um grau. Utilizou-se o modelo de velocidades inicial IASP91. Para a suavidade foi escolhido $\lambda=20$, a Figura 3.6 mostra o resultado da variação deste parâmetro. 


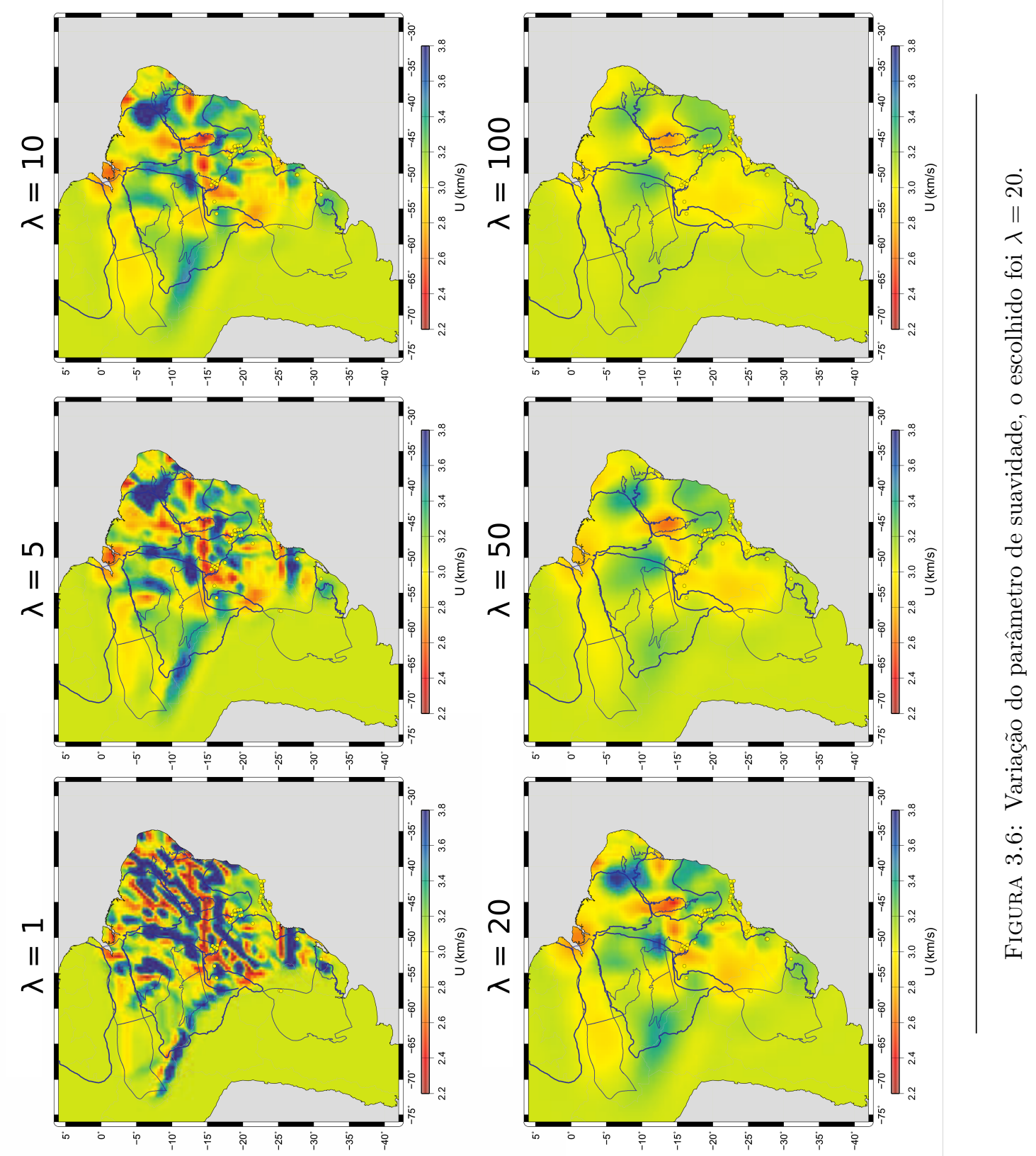




\section{Capítulo 4}

\section{Descrição dos Resultados}

\subsection{Introdução}

Os resultados foram divididos em dois grupos: o primeiro contêm informações de dados utilizando inversão de apenas ondas de superfície geradas por ruído (ANT), e no segundo foi acrescentado ao banco de dados as análises das curvas de dispersão de eventos $(\mathrm{ANT}+\mathrm{SW})$, o que aumentou a área de cobertura do mapa. Nestes mapas a cor vermelha aparece relacionada com as baixas velocidades, enquanto a cor azul se correlaciona com as altas velocidades.

\subsection{Resultados ANT}

Nas Figuras 4.1 a 4.6 os círculos vermelhos representam as estações sismográficas que foram utilizadas no processo de inversão para o período referente à figura. Estas estações foram organizadas em pares que aparecem interligados pelas linhas azuis, chamadas de caminhos. Esses caminhos representam a trajetória na qual foi feita a recuperação da onda Rayleigh pela função de Green. O aumento no número de cruzamentos destes caminhos está relacionado com o aumento da resolução do mapa de velocidade. As Figuras 4.1A a 4.6A representam os mapas de velocidade de grupo em um determinado período para resultados obtidos utilizando-se apenas ANT.

Na Figura 2.2 é mostrado o gráfico de sensibilidade que ajuda a determinar a profundidade à qual os mapas de período estão relacionados. O menor período recuperado para o conjunto de estações disponíveis na rede utilizada foi de $5 \mathrm{~s}$ (Figura 4.1), o resultado obtido possui uma limitação grande pois há poucos cruzamentos, o que permite apenas interpretar uma parte do Cráton São Francisco (CSF) ao sul, a Bacia do Paraná, 
uma parte da Faixa Araçuaí e uma parte da Faixa Brasília. Nota-se boa correlação das anomalias com as principais unidades geológicas da região, as quais serão interpretadas no Capítulo 5 .

A região da Bacia do Paraná foi observada com anomalias de baixa velocidade, especialmente para os períodos entre 10 e $25 \mathrm{~s}$ (Figuras 4.2 a 4.5). Uma anomalia localizada de alta velocidade foi observada na região do Escudo Rio Grandense (latitude: -27 e longitude: -50, Figuras 4.2 a 4.6. O CSF aparece em sua maior parte com anomalias de alta velocidade, com exceção da Bacia do São Francisco que apresenta baixas velocidades (Figuras 4.3 e 4.4). Baixas velocidades predominam na Faixa Brasília (Figura 4.4A), porém algumas anomalias de alta velocidade são observadas em sua parte noroeste, na mesma região onde a densidade de caminhos reduz drasticamente (Figura 4.4B). Diferentemente da Faixa Brasília, na Faixa Araçuaí predominam altas velocidades (Figura $4.4 \mathrm{~A}$ ), porém com uma grande densidade de caminhos (Figura $4.4 \mathrm{~B}$ ).

As características descritas acima, praticamente se mantêm para os períodos até $25 \mathrm{~s}$, com mudanças suaves para os períodos maiores, o que sugere que, para maiores profundidades, o gradiente de velocidade é suave. No entanto, conforme aumenta-se a profundidade as velocidades mais baixas reduzem a sua intensidade ao longo do mapa, permanecendo principalmente nas regiões onde as bacias sedimentares são mais profundas. 


\subsection{Resultados ANT e Tomografia de ondas de superfície $(\mathrm{SW})$}

Para fins de comparação e também com o objetivo de aumentar a densidade dos caminhos, foram incluídos na base de dados caminhos relacionados a eventos sísmicos (pares eventos-estação). Um exemplo de comparação entre os mapas de caminhos sem e com a inclusão de eventos pode ser visto na Figura 4.7. Estes dados foram selecionados para o mesmo período no qual foram selecionados os dados de ruído. A maioria dos eventos utilizados ocorreram na América do Sul principalmente na região andina,o que implica que existe uma direção preferencial E-W. O procedimento de análise da curva de dispersão e inversão que foi aplicado na ANT foi repetido para os caminhos evento-estação. Este tipo de tomografia será denominado de SW para distinguir da ANT. Na Tabela 4.1 é mostrado a comparação do número de caminhos entre ANT e ANT+SW. Nas Figuras 4.9 a 4.12 são mostradas as comparações entre os mapas com apenas ANT e os com $\mathrm{ANT}+\mathrm{SW}$ para o mesmo período. Os pontos amarelos que se encontram nos mapas da tomografia SW são localizações de rochas alcalinas.

$\mathrm{Na}$ Figura 4.8 nota-se que o resultado do período de 5 s para a tomografia $\mathrm{ANT}+\mathrm{SW}$ não é satisfatório, pois devido a distância entre o evento e a estação serem muito maiores quando comparados com a ANT não é possível recuperar ondas com tais períodos, limitando assim a análise de períodos pequenos para ANT+SW. A partir da Figura 4.9 nota-se que os mapas são bastante concordantes, o que reforça a confiabilidade nos resultados da ANT. Além disso, nos mapas de $\mathrm{ANT}+\mathrm{SW}$ regiões que possuíam baixa cobertura de raios podem ser interpretadas, como o CSF por completo e a Província Borborema, no entanto, é válido ressaltar que apesar do aumento na densidade dos caminhos, não houve um grande aumento na quantidade de cruzamentos dos caminhos já que os caminhos relacionados a eventos possuem uma direção preferencial. 


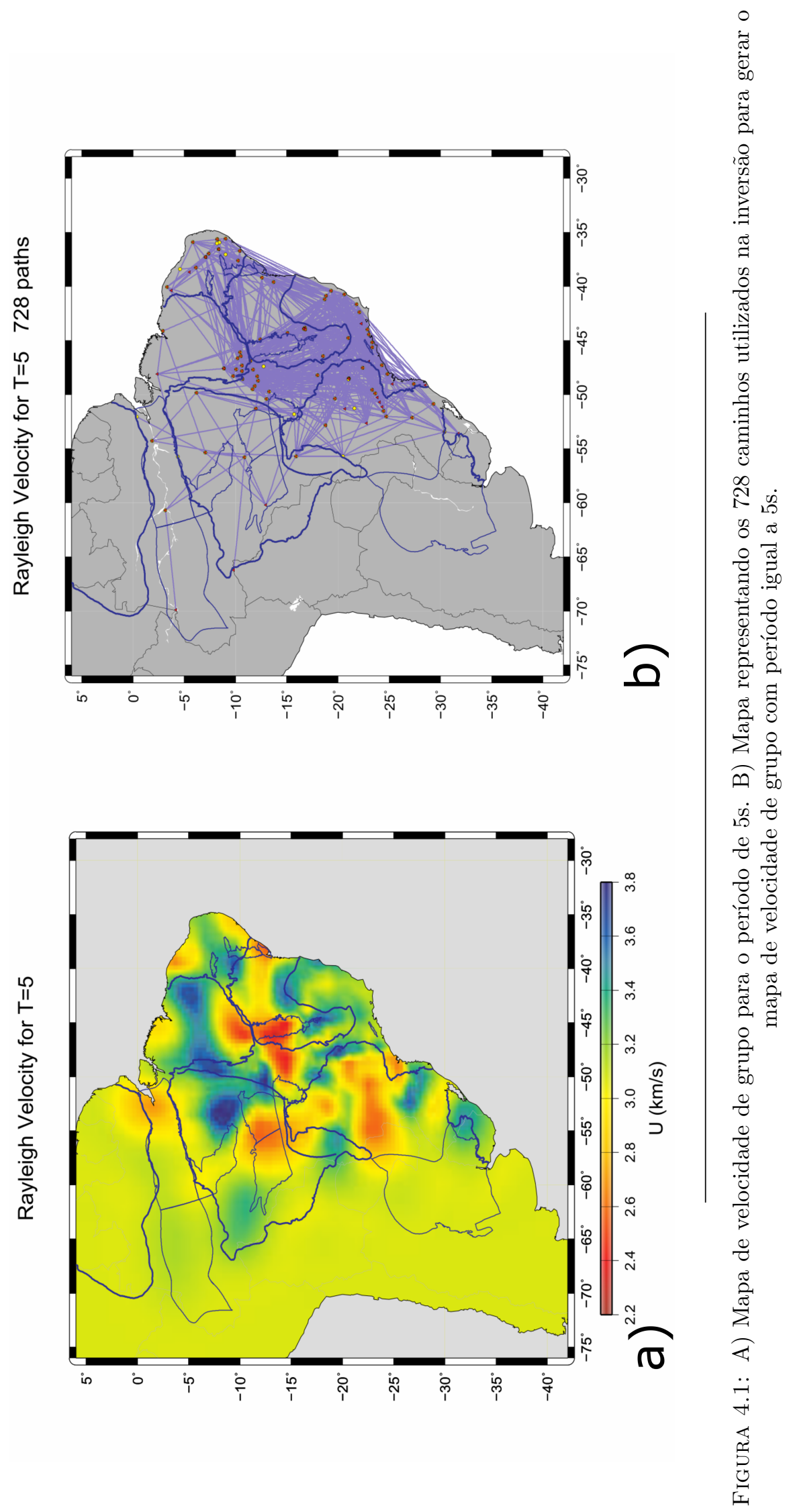




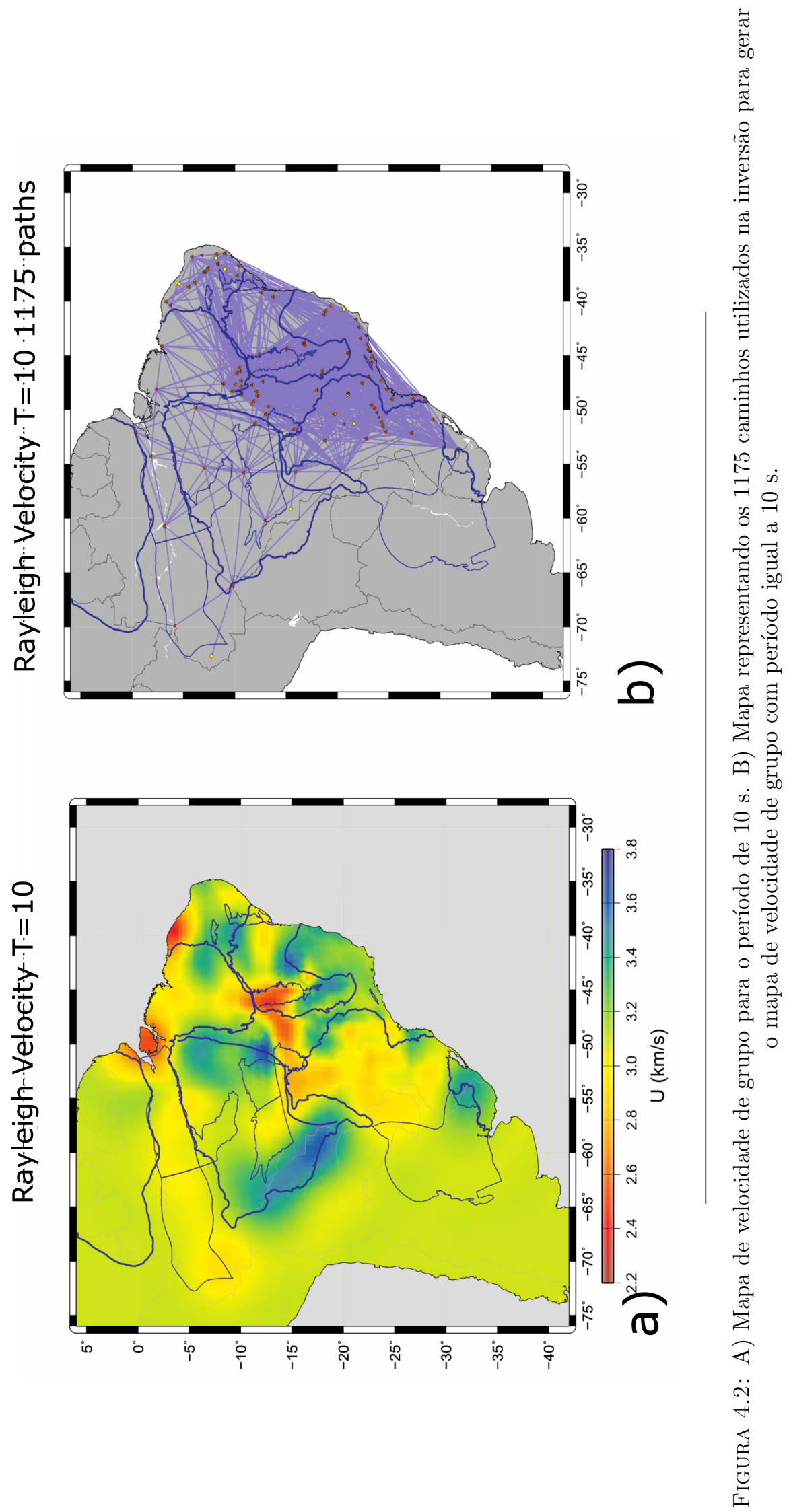



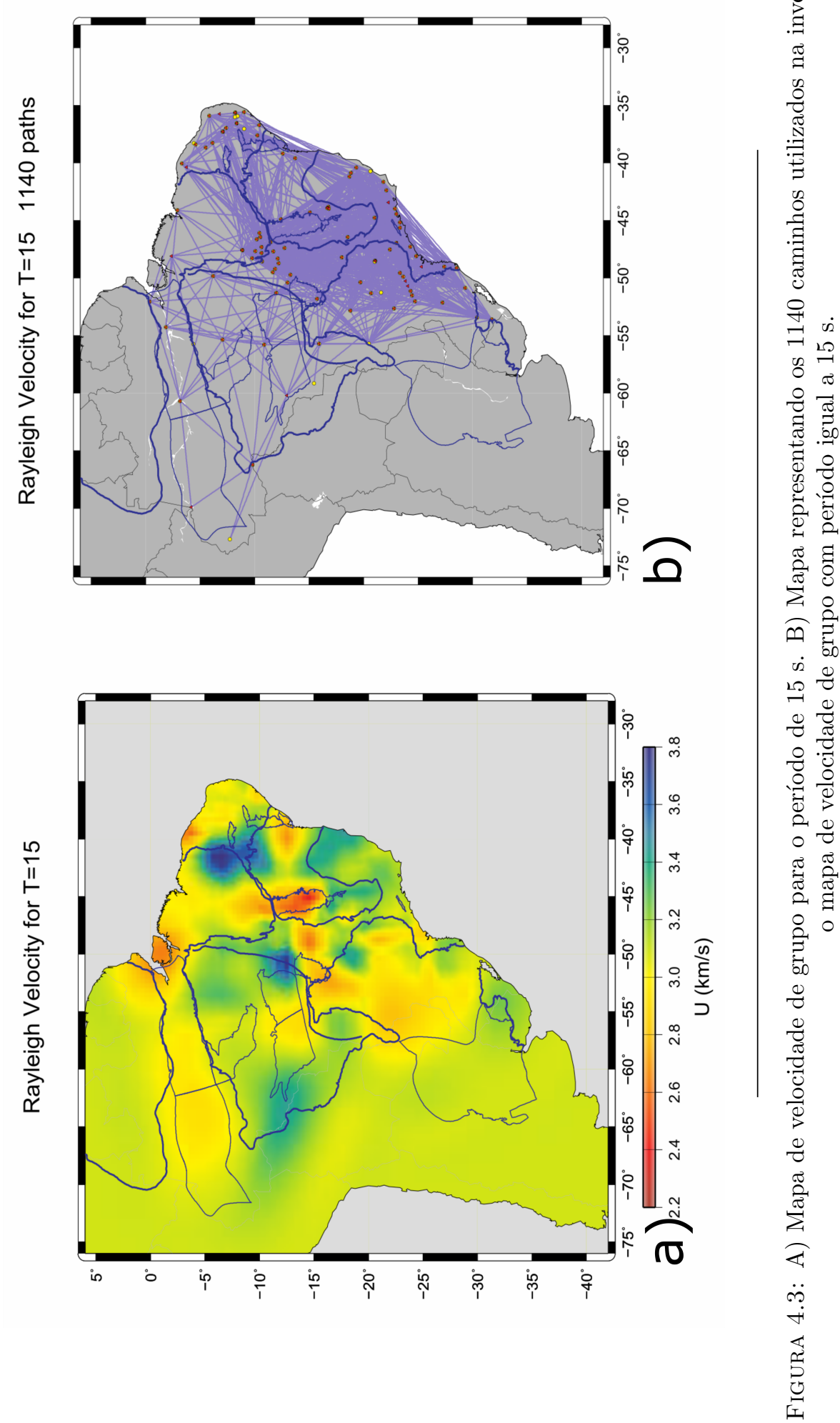

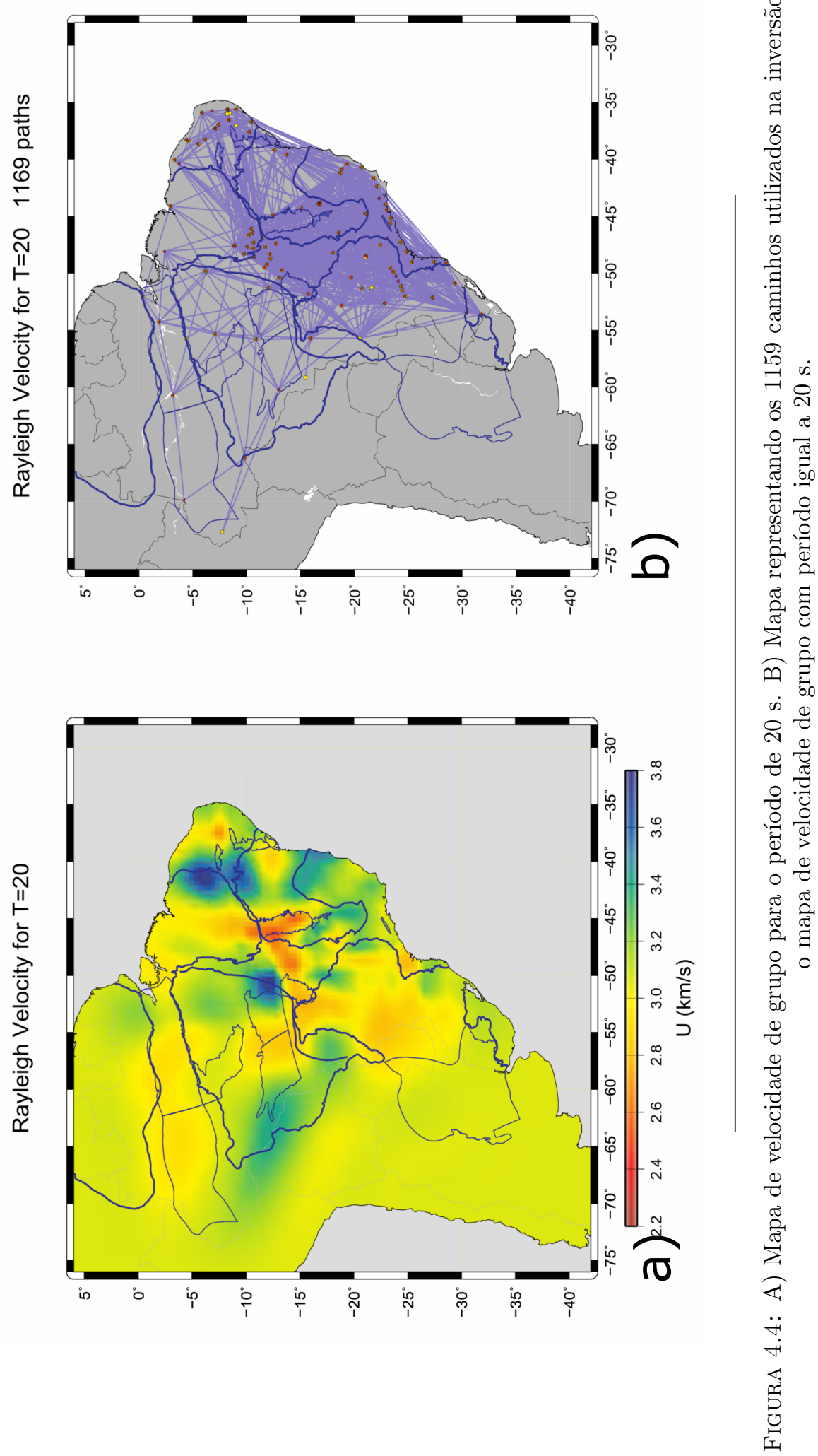


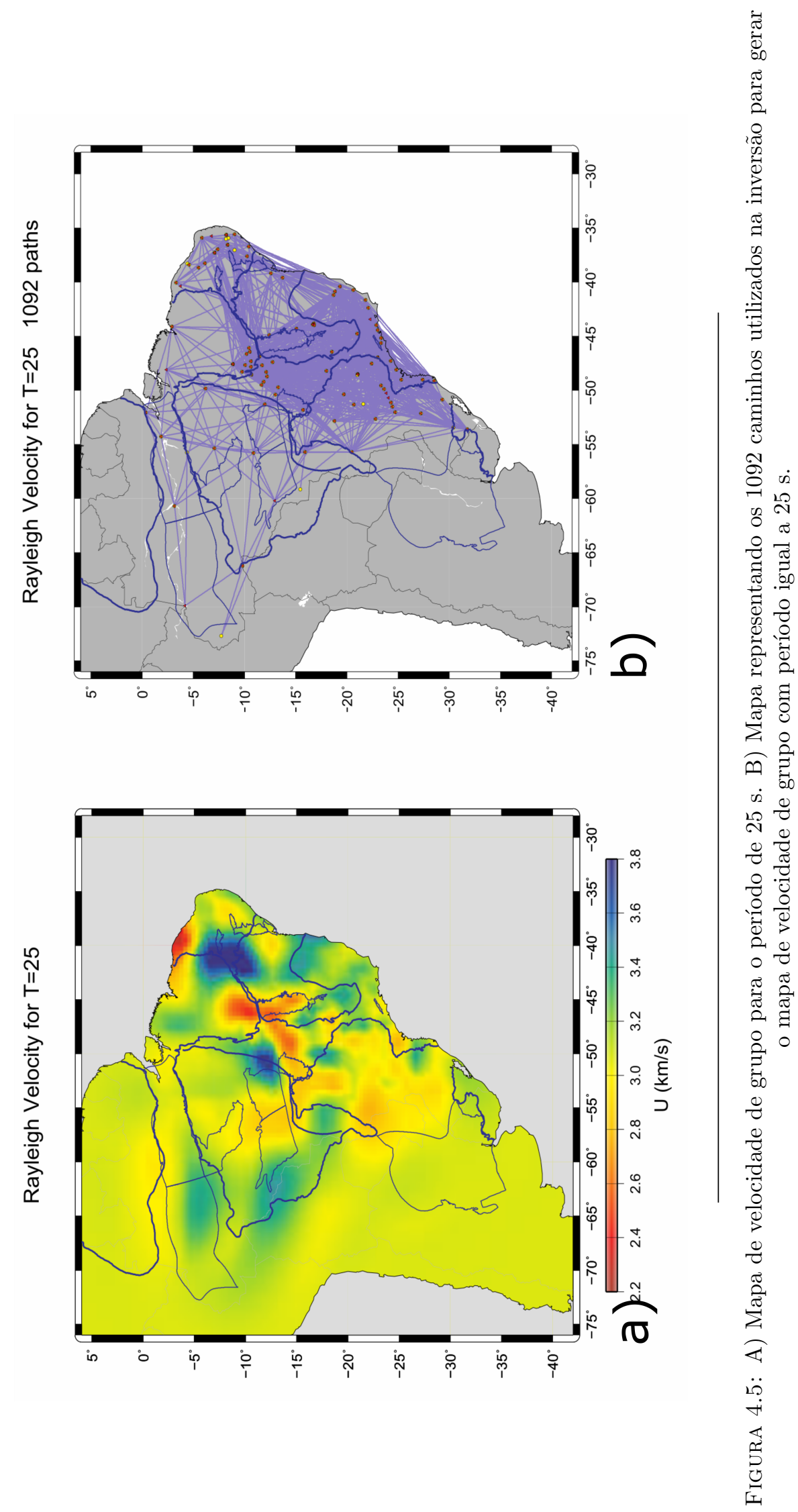




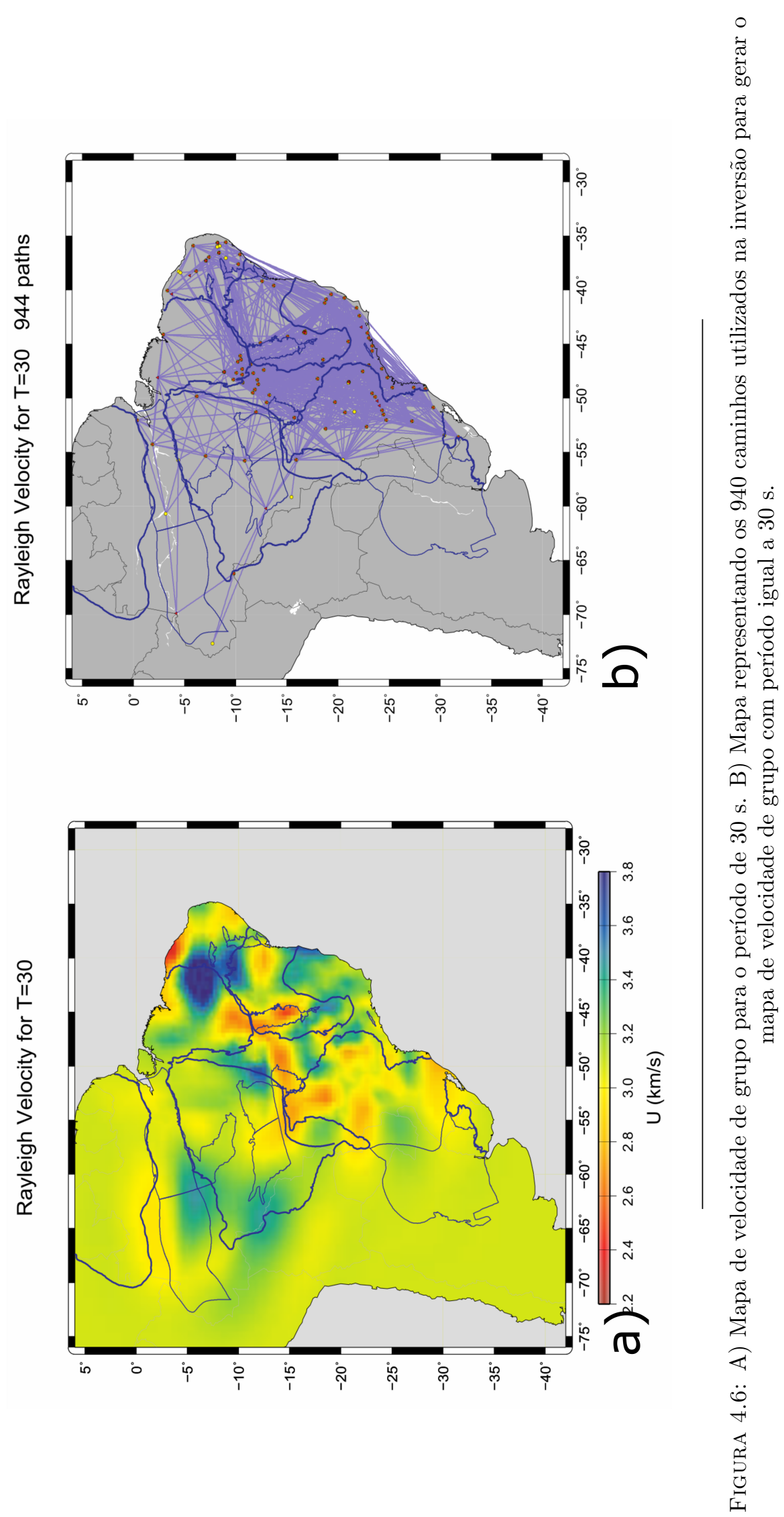




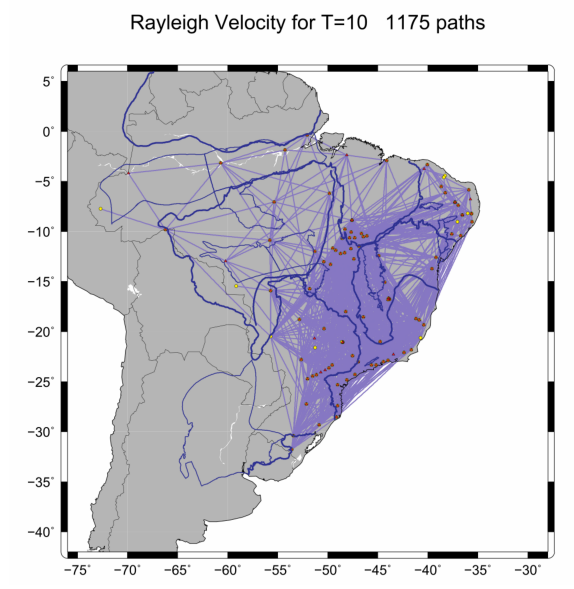

a)

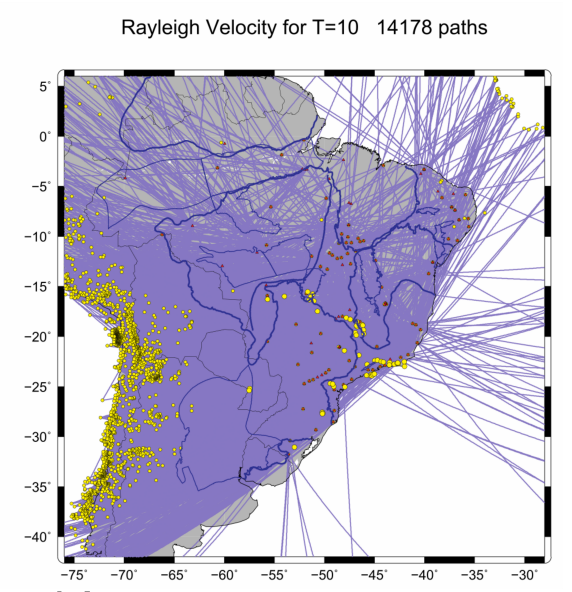

b)

FigurA 4.7: Comparação dos resultados dos mapas de caminho para o período de 10 s.

\begin{tabular}{|c|c|c|}
\hline Período & ANT & ANT+SW \\
\hline 5 & 728 & 2028 \\
\hline 10 & 1175 & 14178 \\
\hline 15 & 1140 & 19788 \\
\hline 20 & 1159 & 20132 \\
\hline 25 & 1092 & 17846 \\
\hline 30 & 944 & 15502 \\
\hline
\end{tabular}

TABELA 4.1: Número de caminhos utilizados para cada período utilizando apenas ruído (ANT) e ruído e evento $(\mathrm{ANT}+\mathrm{SW})$. 

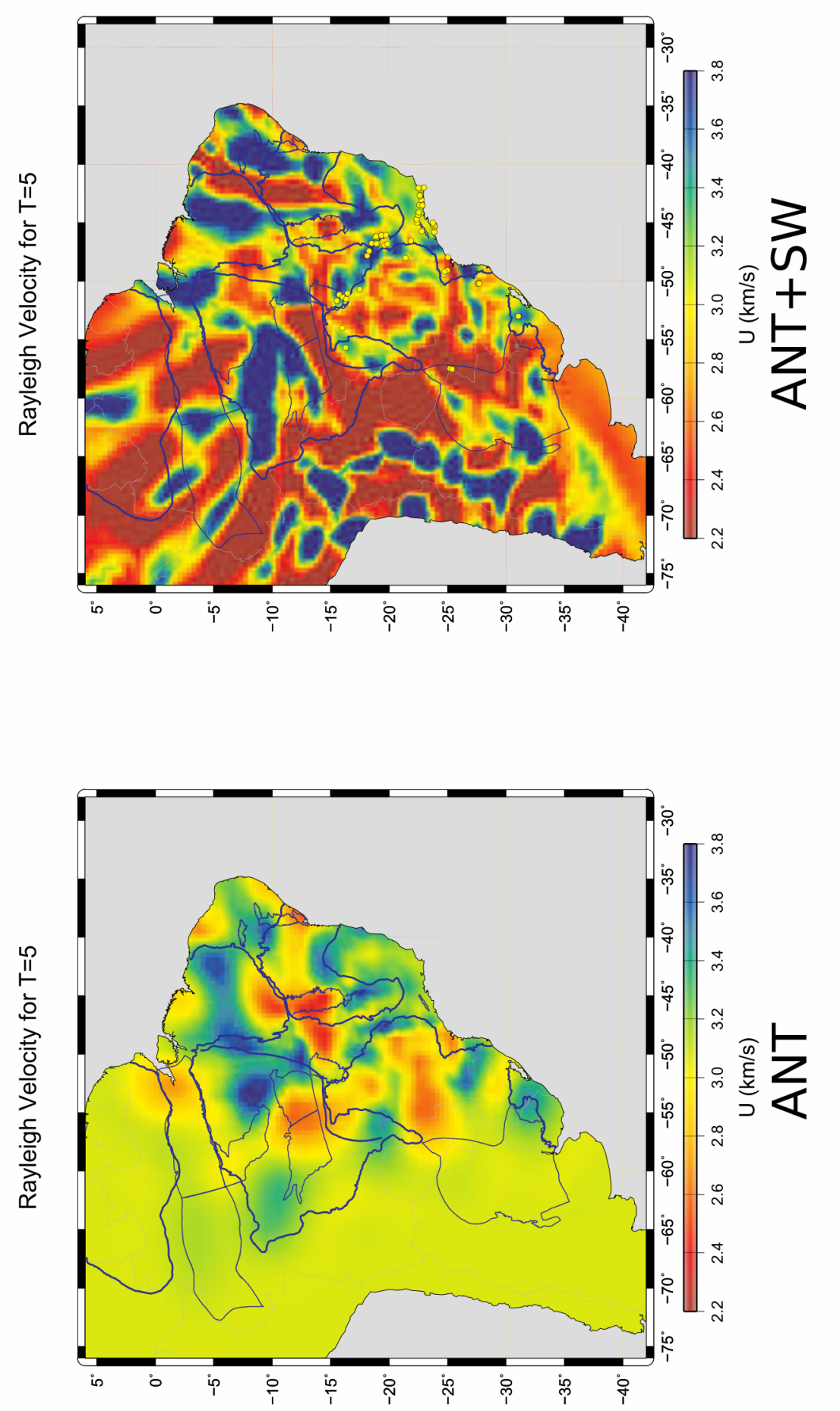

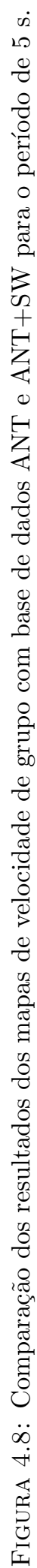




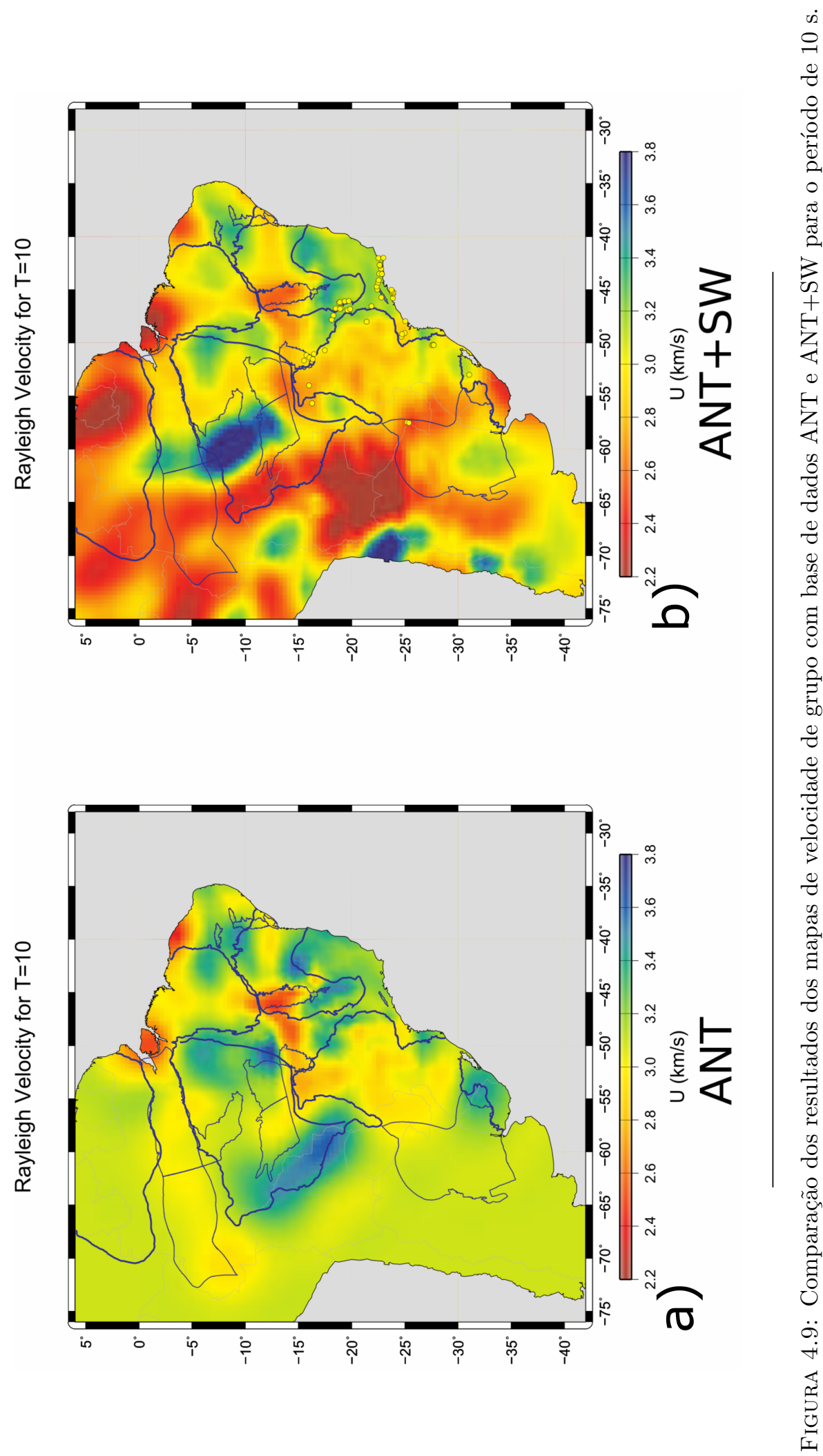




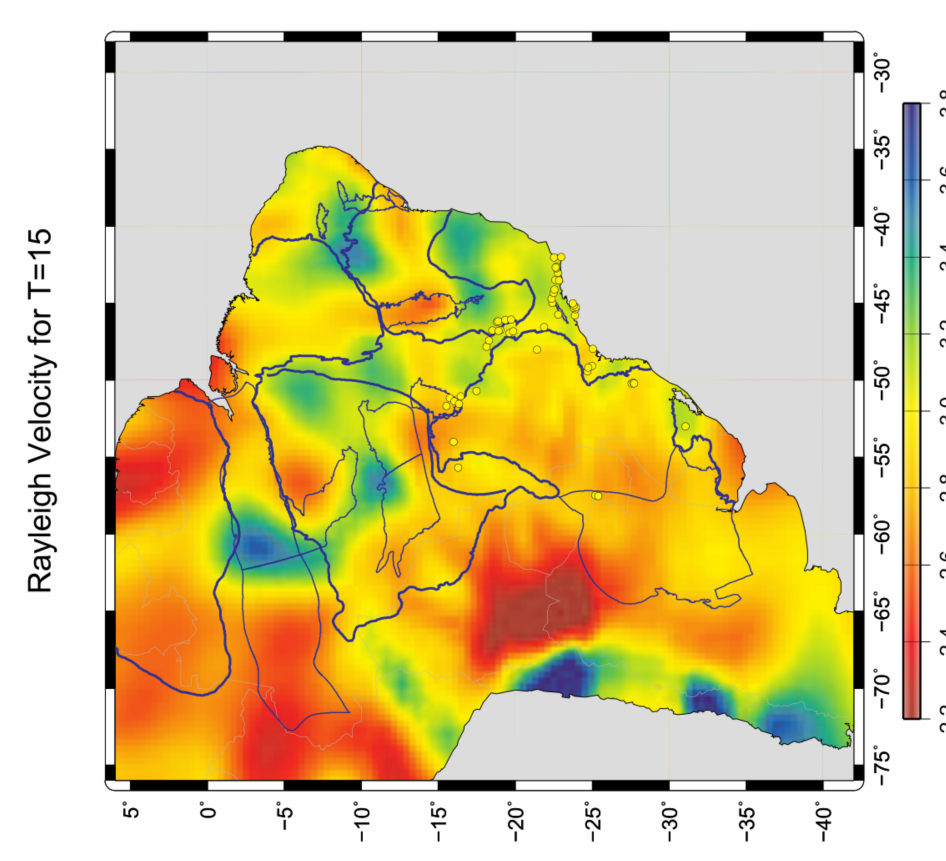

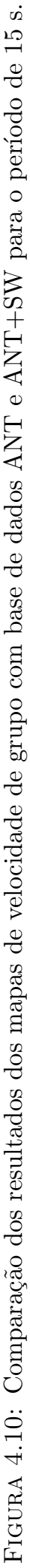




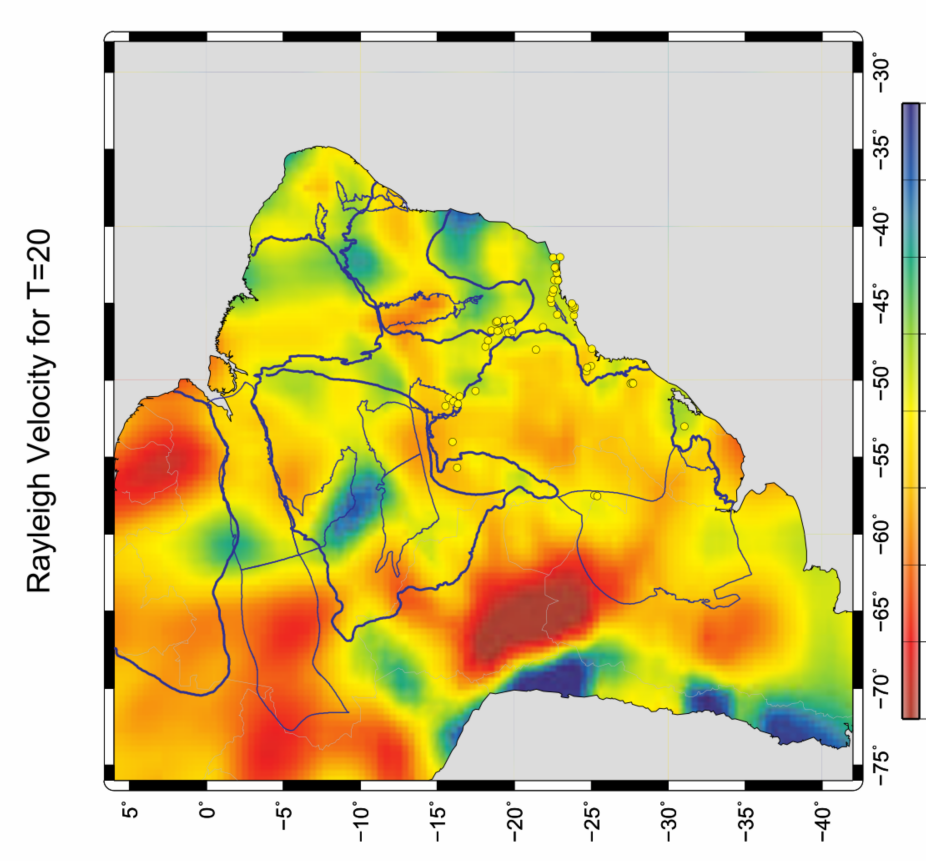

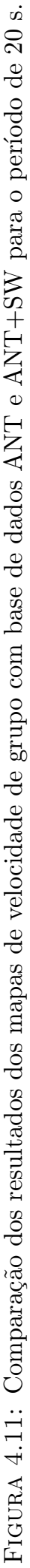




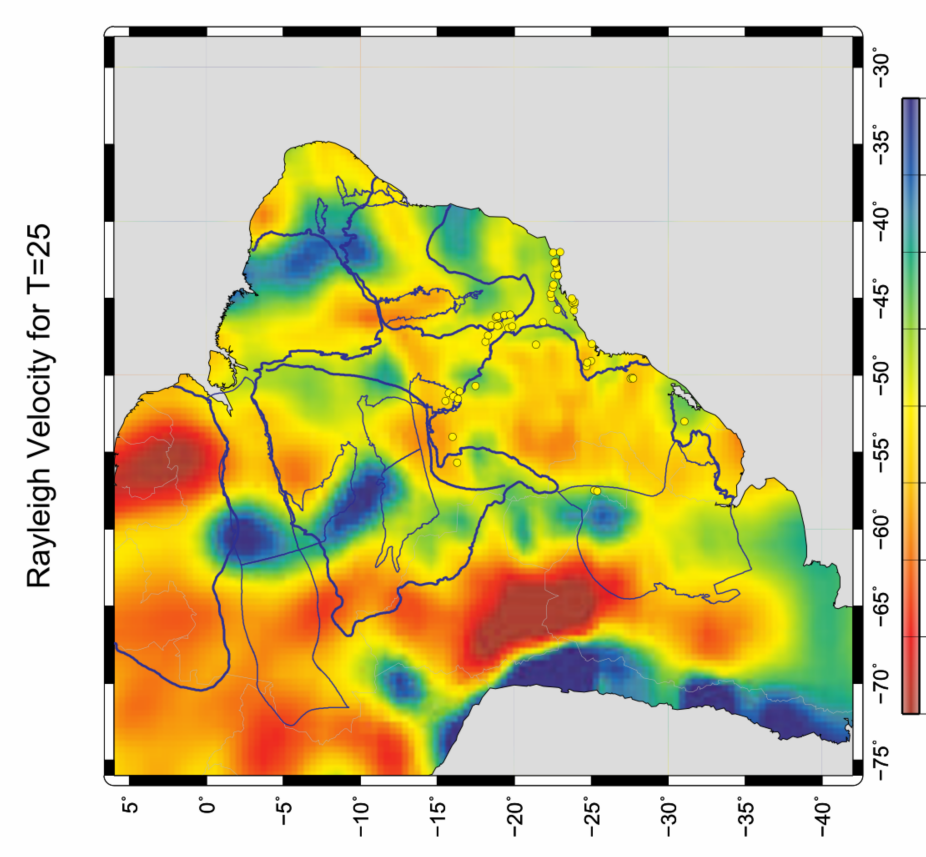

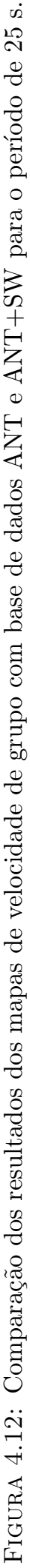




\section{Capítulo 5}

\section{Discussão dos Resultados}

\subsection{Introdução}

Devido as ondas de superfície normalmente percorrem a parte mais próxima da superfície da Terra, principalmente àquelas recuperadas a partir do ruído sísmico, as anomalias resultantes podem estar associadas a estruturação tectônica crustal, diferentemente da tomografia de ondas de corpo que normalmente investiga profundidades mantélicas. A interpretação destas anomalias em geral considera que as velocidades mais baixas estão relacionadas à bacias sedimentares (e.g. Shapiro et al. (2005)) e a regiões de fraquezas da crosta, enquanto as velocidades mais altas se referem a regiões tectonicamente estáveis, como os blocos arqueanos (e.g. Yao, Hilst e Maarten (2006)).

Ao se analisar os mapas de inversão deve-se levar em conta que nem todas as áreas são robustas o suficiente para uma interpretação confiável, visto que é necessário que a região seja cortada por vários caminhos com diferentes azimutes para melhor determinação da velocidade naquela posição. Desta forma, buscou-se interpretar apenas as áreas com boa cobertura e distribuição azimutal de percursos. Além disso, regiões com poucos cruzamentos não foram interpretadas, visto que representam extrapolação do sistema de equações causando anomalias que podem não representar a realidade, como é o caso do Cráton Amazônico e da região andina. Devido à disposição das estações na área de estudo e também a disponibilidade de dados, as regiões com maior resolução foram as Províncias Borborema e Tocantins, o Cráton do São Francisco e o norte da Bacia do Paraná. Algumas outras regiões pontuais puderam ser imageadas, porém com menor resolução, como por exemplo o Escudo Rio Grandense.

As profundidades interpretáveis baseiam-se no gráfico de sensibilidade apresentado na Figura 2.4, a qual relaciona os diferentes períodos com a profundidade. Dessa forma, 
para cada mapa de velocidade de grupo apresentado, será considerada na interpretação a profundidade correspondente.

Nos resultados, o comportamento geral das anomalias segue o padrão esperado, quando comparado com as principais unidades geológicas definidas nos estudos mais recentes. No entanto, localmente, algumas anomalias fogem deste padrão. Na porção noroeste do CSF (oeste da Bahia), por exemplo, a anomalia observada contradiz o padrão de altas velocidades que é esperado para regiões cratônicas, o que provavelmente deve ser resultante da baixa densidade de caminhos.

\subsection{Bacias Sedimentares}

Para os mapas de menores períodos, nas regiões interpretáveis (com boa densidade de cruzamentos), as anomalias de baixa velocidade possuem boa correlação espacial com as bacias sedimentares, como pode ser visto na Figura 5.1 .

A bacia do Paraná foi bem delimitada pelas anomalias de baixa velocidade encontras pela ANT, o que se torna mais evidente quando se observa o mapa incluindo os percursos relacionados a eventos (Figuras 4.7 e 4.10 ), os quais melhoram a resolução na parte sudeste da bacia no seu limite com a Argentina. No entanto, conforme foi descrito no capítulo anterior, para os resultados apenas da ANT, aumentado-se os períodos, ou seja, a profundidade, existe uma tendência destas anomalias se restringem à sua porção central, sugerindo que o seu depocentro foi imageado. Uma confirmação deste comportamento poderia ser obtida com a instalação de mais estações circundando a bacia (com distâncias menores) principalmente na sua porção sudeste, onde existe baixa cobertura de caminhos. Atualmente existe um projeto em andamento coordenado pelo Centro de Sismologia da Universidade de São Paulo que prevê a instalação de estações nesta região.

Uma intensa anomalia de baixa velocidade foi observada na parte norte do CSF na região da sua bacia sedimentar (Figura 5.1A, elipse branca). Esta anomalia é robusta já que está presente nos mapas de todos períodos da ANT, e também devido a alta densidade de caminhos na região (Figura 4.3). No entanto, a maioria dos caminhos possui direção preferencial N-S, o que não permite delimitá-la de forma adequada, mesmo estando as maiores intensidades contidas nos seus limites geológicos.

O sul da Bacia do Parnaíba (Figura 5.1A, elipse preta) é entrecortada por alguns caminhos, e a anomalia resultante desses caminhos apresentam uma tendência de baixa velocidade, assim como as que foram encontradas para a Bacia do Paraná e do São Francisco. Porém, também não é possível delimitar a bacia, pois a área de cobertura 
dos caminhos é bastante baixa além da baixa cobertura azimutal, e por isso a anomalia no restante da bacia bacia apresenta velocidades altas. Para poder melhor definir a bacia é necessário o adensamento de estações sismográficas na mesma. Na Figura 4.1 fica evidente a diferença entre a parte recoberta por caminhos e a que não é.

\subsection{Faixas Móveis e Cráton do São Francisco}

Na Faixa Araçuaí foram observadas altas velocidades (Figura 5.3A). Eram esperadas, para esta faixa, baixas velocidades por se tratar de uma região que sofreu orogenia (PEDROSA-SOARES et al., 2013). Este efeito poderia estar relacionado com o embasamento cratônico parte do CSF que se estenderia sob a faixa para além dos limites superficiais daquele Cráton. Este comportamento pode ser observado em profundidades mantélicas (Figura 5.3B) nos resultados de tomografia sísmica com ondas de corpo (ROCHA; SCHIMMEL; ASSUMPÇÃO, 2011). Os resultados obtidos no presente trabalho, mostram este comportamento para profundidades crustais, sugerindo que o embasamento cratônico da Faixa Araçuaí se encontra mais próximo da superfície (entre 20 e 30 $\mathrm{km}$ ), o que implica que a região dobrada é superficial, e que o CSF se estende para leste (Paleocontinente São Franciscano - PSF Alkmim et al. (1993)).

Na Faixa Brasília foi observada uma anomalia de baixa velocidade entre as Bacias do Bananal e do Paraná (Figura 5.1, elipse rosa). Esta região é uma das que possui maior cobertura de percursos com boa distribuição azimutal, e desta forma, esta anomalia é robusta. Apesar de não existirem sedimentos, esta é uma região de fraqueza listosférica, com ocorrência de relativamente alta sismicidade para os padrões brasileiros (ROCHA et al. 2016). Além disso, esta região coincide com uma das mais importantes descontinuidades estruturais da América do Sul, o Lineamento Transbrasiliano (LTB), o qual define limites entre diferentes domínios crustais (NEVES; FUCK, 2014).

Segundo (ALKMIM et al., 1993), com base na interpretação de dados gravimétricos (USSAMI, 1993), sob a região da Faixa Brasília estaria parte do PSF e desta forma esta teria um embasamento cratônico (Figura 5.2). Este comportamento foi observado também em resultados de tomografia sísmica (Figura 5.3, Rocha, Schimmel e Assumpção (2011)) para profundidades mantélicas. Neste caso, segundo o mesmo raciocínio apresentado para a Faixa Araçuaí, seriam esperadas altas velocidades para esta região nos resultados de ANT. Contudo, devido a predominância de baixas velocidades nesta região, não é possível afirmar que o embasamento cratônico desta Faixa esteja em profundidades crustais (Figura 5.4), concordando com os resultados de Função do Receptor ASSUMPÇÃO et al., 2013) e Refração Sísmica Profunda (SOARES et al., 2006). Esta diferença entre a profundidade do embasamento entre as duas Faixas adjacentes ao CSF 
sugere duas interpretações: A primeira seria que a atividade tectônica na margem oeste da PSF foi mais intensa do que na sua margem leste, causando mais deformação da crosta; A segunda seria que a PSF estaria basculada para oeste.

No CSF, por ser tratar de um terreno mais estável, foram observadas altas velocidades nos resultados obtidos pela ANT, em especial na sua porção Nordeste e Sul, onde esta última é considerada como a parte mais preservada deste cráton (PEREIRA; FUCK, 2007). Na Figura 5.3 é apresentado uma comparação entre os resultados da ANT e da Tomografia de Onda de Corpo ROCHA; SCHIMMEL; ASSUMPÇÃO, 2011) para uma profundidade de $150 \mathrm{~km}$. No resultado da Tomografia de Onda de Corpo, devido as profundidades imageadas, os efeitos das bacias já não são mais evidentes dentro do CSF, ressaltando a resposta mais rasa da ANT já que esta sofre influência direta da presença dos sedimentos superficiais nos períodos trabalhados. 


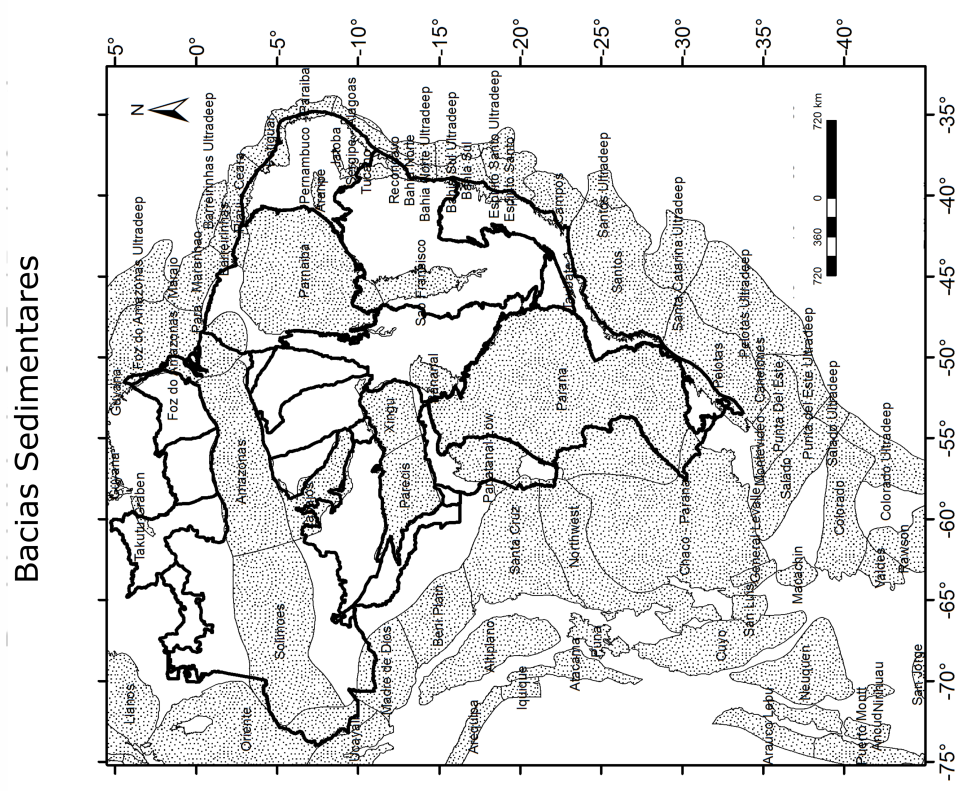

\begin{tabular}{|r|}
\hline \\
$\vdots$ \\
0 \\
0 \\
0
\end{tabular}

जี

8

苞

ฮึ

悹

与

ธั

ธิ

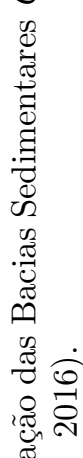

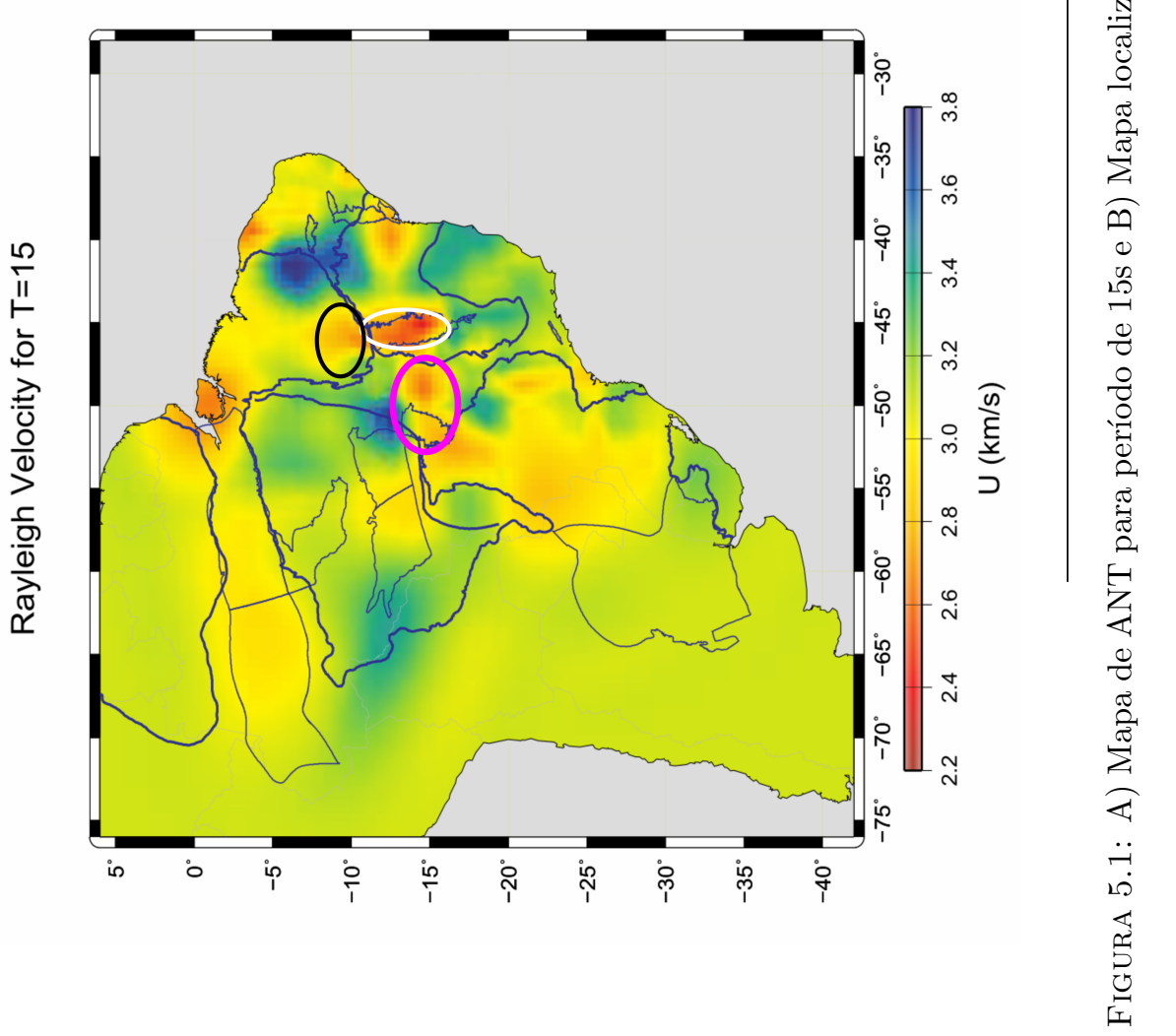




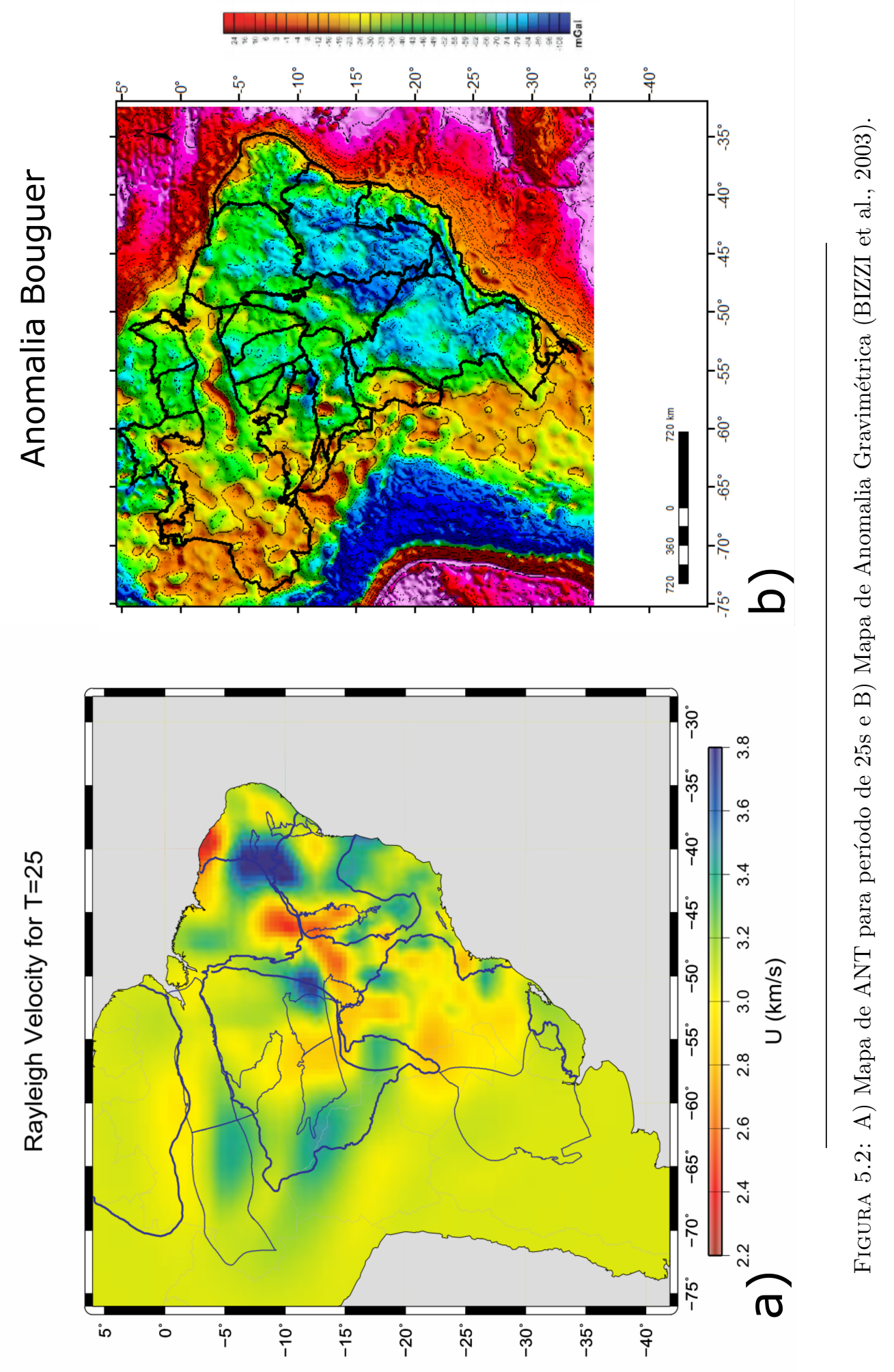



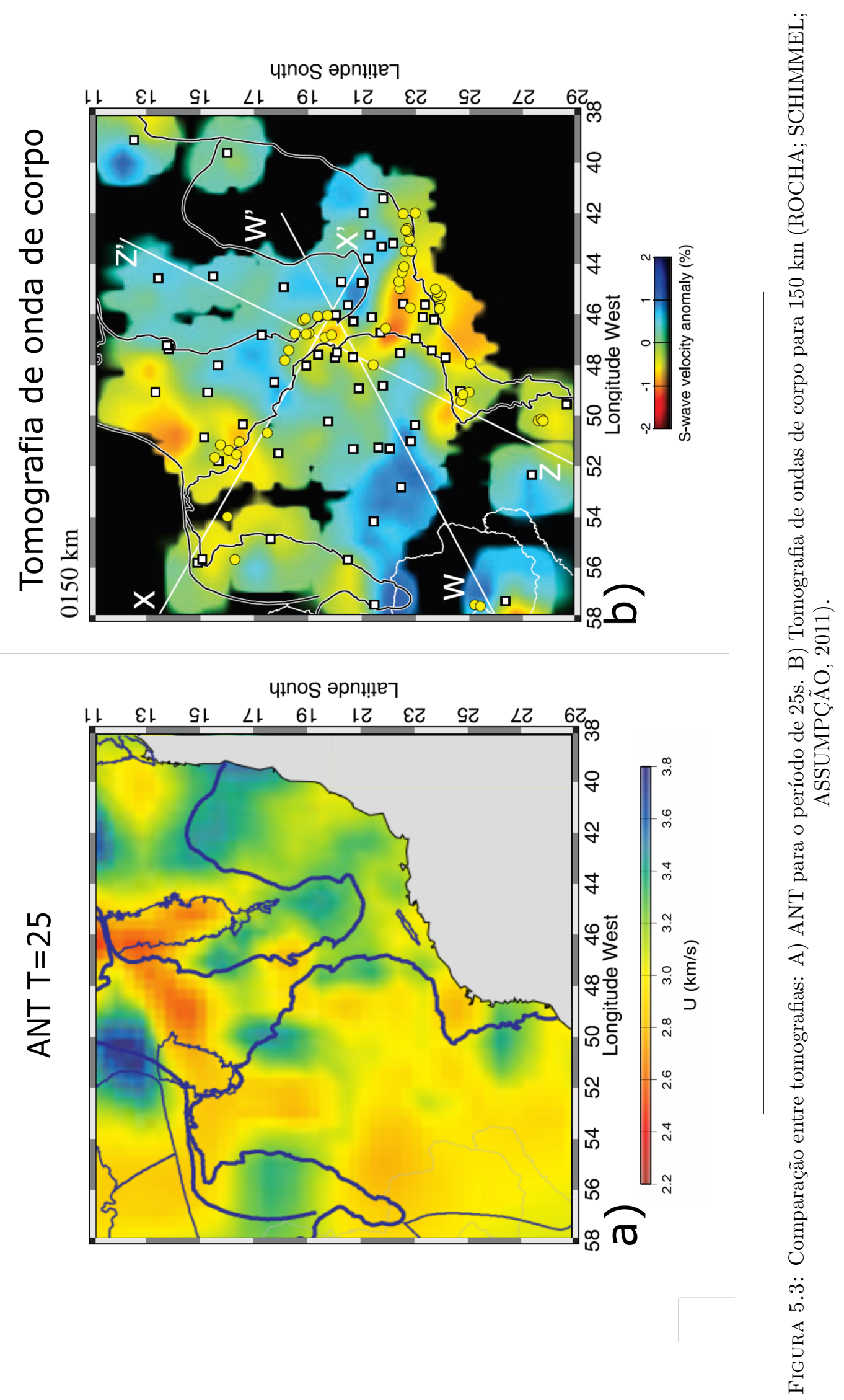


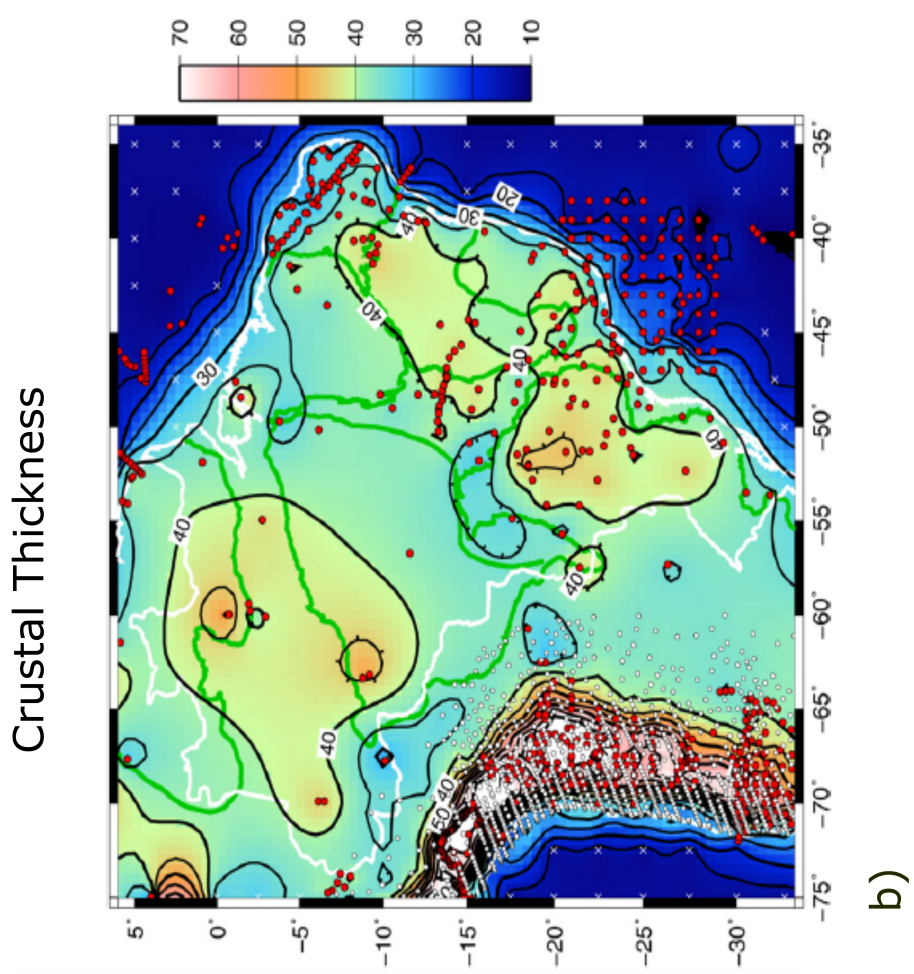

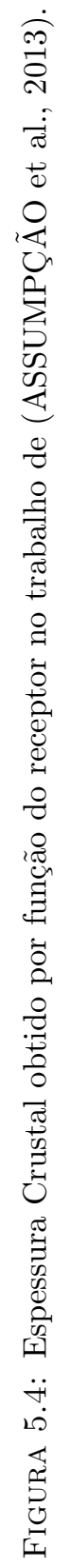

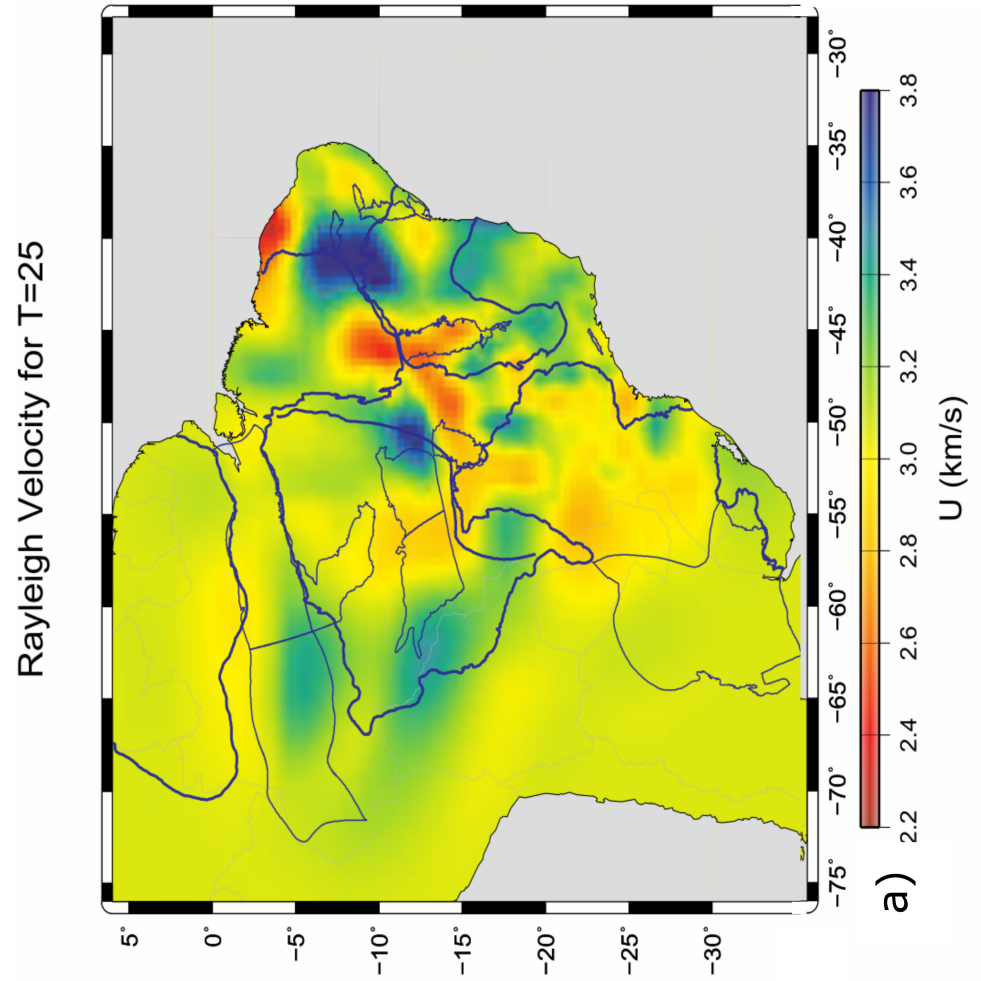




\section{Capítulo 6}

\section{Conclusões}

Neste trabalho, o método da ANT foi aplicado para estudo da estrutura crustal no Brasil. A partir dos resultados obtidos foi possível obter informações geológicas e fazer inferências sobre a evolução tectônica da parte leste da Plataforma Sul-Americana. Além disso, foram testados diferentes procedimentos metodológicos para a utilização da técnica.

A comparação entre as metodologias de correlação cruzada mostrou que a técnica que leva em consideração a fase (PCC) é mais eficiente para a recuperação dos sinais de interesse do que a técnica que leva em consideração a amplitude (CCGN).

Os testes realizados para a determinação do número mínimo de dados a serem empilhados para a recuperação da forma de onda indicam que são necessários 60 dias de registro (considerando empilhamento de registros de 24 horas).

A baixa cobertura de estações em algumas regiões, tal como a região norte, não permitiu resolver as estruturas relacionadas, não sendo possível interpretá-las.

Para melhorar a recuperação das ondas Rayleigh para os maiores períodos, devido o baixo número de caminhos, foram utilizados dados de eventos. No entanto, apenas algumas regiões tiveram uma melhora significativa, já que como boa parte dos caminhos foram de eventos telessísmicos estes carregavam informações de regiões fora da área de estudo.

A utilização da ANT permitiu delimitar a bacia do Paraná, e para períodos maiores, a tendência de concentração das anomalias na parte central da bacia sugere que o seu depocentro foi imageado. Contudo, para melhorar a resolução do mesmo seria necessário utilizar uma rede mais densa na região. 
A bacia do São Francisco foi identificada com baixas velocidades e a sua anomalia corresponde com os limites geológicos da mesma, com uma perda de resolução em sua porção norte.

A bacia do Parnaíba possui tendências de baixa velocidade, no entanto, não pôde ser caracterizada devido a baixa cobertura de caminhos na região.

A Faixa Araçuaí apresenta velocidades altas o que sugere uma característica cratônica para o seu embasamento crustal, concordando com os resultados de tomografia de onda de corpo para o manto litosférico.

A Faixa Brasília apresenta comportamento de baixa velocidade conforme o esperado para que sofreram intenso tectonismo. A anomalia de baixa velocidade observada na região coincide com o Lineamento Transbrasiliano.

Considerando que a anomalia de alta velocidade na Faixa Araçuaí representa o seu embasamento cratônico, e que este está mais raso do que o embasamento da Faixa Brasília, foi possível estabelecer duas interpretações em relação à geometria da PSF: 1) A porção oeste da PSF teria sofrido uma maior deformação do que a sua porção leste; 2) A PSF estaria basculada na direção oeste.

A parte sul do CSF apresentou altas velocidades concordado com os trabalhos que indicam esta região como a parte mais estável do Cráton (seu núcleo Arqueano). 


\section{Referências Bibliográficas}

AKI, K. Space and time spectra of stationary stochastic waves with special reference to microtremors. Bull. Earthquake Res. Inst.Tokyo Univ., v. 35, p. 415-456, 1957.

AKI, K.; RICHARDS, P. G. Quantitative seismology. [S.l.: s.n.], 2002.

ALKMIM, F.; CRUZ, S. Cratógenos, aulacogenos, orógenos e suas interaçoes: O caso do cráton do são francisco-congo e sistemas brasilianos/pan-africanos adjacentes. III Simpósio sobre o Cráton do Sao Francisco, p. 185-187, 2005.

ALKMIM, F. F. et al. Arcabouço tectônico do cráton do são francisco-uma revisão. $O$ Cráton do São Francisco, SBGSGMCNPq Salvador, v. 1, p. 45-62, 1993.

ALMEIDA, F. d. Geochronological division of the precambrian of south america. Brazilian Journal of Geology, v. 1, n. 1, p. 13-21, 1971.

ALMEIDA, F. d. O cráton do paramirim e suas relações com o do são francisco. Simpósio sobre o Cráton do São Francisco e suas Faixas marginais, SBG/Núcleo BA/SE Salvador, v. 1, p. 1-10, 1981.

ALMEIDA, F. F. M.; NEVES, B. B. de B.; CARNEIRO, C. D. R. The origin and evolution of the south american platform. Earth-Science Reviews, Elsevier, v. 50, n. 1, p. $77-111,2000$.

ASSUMPÇÃO, M. et al. Crustal thickness map of brazil: Data compilation and main features. Journal of South American Earth Sciences, Elsevier, v. 43, p. 74-85, 2013.

BACKUS, G.; GILBERT, J. Numerical applications of a formalism for geophysical inverse problems. Geophysical Journal International, Oxford University Press, v. 13, n. 1-3, p. 247-276, 1967.

BARMIN, M.; RITZWOLLER, M.; LEVSHIN, A. A fast and reliable method for surface wave tomography. In: Monitoring the Comprehensive Nuclear-Test-Ban Treaty: Surface Waves. [S.1.]: Springer, 2001. p. 1351-1375.

BENSEN, G. et al. Processing seismic ambient noise data to obtain reliable broad-band surface wave dispersion measurements. Geophysical Journal International, Oxford University Press, v. 169, n. 3, p. 1239-1260, 2007.

BIANCHI, M. et al. Operational Procedures of Contributing Agencies, The Brazilian Seismographic Network Historical Overview and Current Status. 2016.

BIZZI, L. A. et al. Geologia, tectônica e recursos minerais do brasil. CPRM, Brasília, 2003. 
CAMPILLO, M.; PAUL, A. Long-range correlations in the diffuse seismic coda. Science, American Association for the Advancement of Science, v. 299, n. 5606, p. 547-549, 2003.

CGG Geoconsulting Robertson Sedimentary Basins. 2016. Disponível em: 〈http: //www.datapages.com/gis-map-publishing-program/gis-open-files/global-framework/ robertson-tellus-sedimentary-basins-of-the-world-map).

$\mathrm{CHO}, \mathrm{K}$. et al. Imaging the upper crust of the korean peninsula by surface-wave tomography. Bulletin of the Seismological Society of America, Seismological Society of America, v. 97, n. 1B, p. 198-207, 2007.

CLAERBOUT, J. F. Synthesis of a layered medium from its acoustic transmission response. Geophysics, Society of Exploration Geophysicists, v. 33, n. 2, p. 264-269, 1968.

COLLAÇO, B. et al. Preliminary results of ambient noise tomography in the borborema province. In: XVI Congreso Peruano de Geología. [S.l.]: SEG, 2012.

CORDANI, U. G. Estudo preliminar de integraçao do Pré-Cambriano com os eventos tectônicos das bacias sedimentares Brasileiras. [S.l.]: Petrobrás, Centro de Pesquisas e Desenvolvimento Leopoldo A. Miguez de Mello, Setor de Informação Técnica e Propriedade Industrial, 1984.

DIAS, R. C.; JULIÀ, J.; SCHIMMEL, M. Rayleigh-wave, group-velocity tomography of the borborema province, ne brazil, from ambient seismic noise. Pure and Applied Geophysics, Springer, v. 172, n. 6, p. 1429-1449, 2015.

DZIEWONSKI, A.; BLOCH, S.; LANDISMAN, M. A technique for the analysis of transient seismic signals. Bulletin of the seismological Society of America, Seismological Society of America, v. 59, n. 1, p. 427-444, 1969.

FENG, M.; ASSUMPÇAO, M.; LEE, S. Van der. Group-velocity tomography and lithospheric s-velocity structure of the south american continent. Physics of the Earth and Planetary Interiors, Elsevier, v. 147, n. 4, p. 315-331, 2004.

FENG, M.; LEE, S. Van der; ASSUMPÇÃO, M. Upper mantle structure of south america from joint inversion of waveforms and fundamental mode group velocities of rayleigh waves. Journal of Geophysical Research: Solid Earth, Wiley Online Library, v. 112, n. B4, 2007.

FYFE, W.; LEORNADO, J. O. Ancient metamorphic-migmatite belts. the brazilian atlantic coast: the african connection. Brazilian Journal of Geology, v. 4, n. 4, p. 247-251, 1974.

GOUTORBE, B.; COELHO, D. L. de O.; DROUET, S. Rayleigh wave group velocities at periods of 6-23 s across brazil from ambient noise tomography. Geophysical Journal International, Oxford University Press, v. 203, n. 2, p. 869-882, 2015.

HADAMARD, J. Lectures on Cauchy's Problem in Linear Partial Differential Equations. [S.l.]: Dover Publications, 2014. ISBN 9780486781488.

HASUI, Y. et al. Geologia do Brasil. [S.l.: s.n.], 2012. 
HORIKE, M. Inversion of phase velocity of long-period microtremors to the s-wave-velocity structure down to the basement in urbanized areas. Journal of Physics of the Earth, Japan Publications Trading, v. 33, n. 2, p. 59-96, 1985.

LAY, T.; WALLACE, T. Modern Global Seismology. [S.l.]: Elsevier Science, 1995. (International Geophysics). ISBN 9780080536712.

LEVSHIN, A. L. et al. Minor-arc and major-arc global surface wave diffraction tomography. Physics of the Earth and Planetary Interiors, Elsevier, v. 149, n. 3, p. 205-223, 2005.

LIN, F.-C. et al. Ambient noise rayleigh wave tomography of new zealand. Geophysical Journal International, Oxford University Press, v. 170, n. 2, p. 649-666, 2007.

NEVES, B. B. B.; FUCK, R. A. The basement of the south american platform: Half laurentian (n-nw) + half gondwanan (e-se) domains. Precambrian Research, Elsevier, v. 244 , p. $75-86,2014$.

NOR, A. V. et al. Ambient noise surface wave tomography of the iberian peninsula: Implications for shallow seismic structure. Geophysical Research Letters, Wiley Online Library, v. 34, n. 11, 2007.

OKADA, H. The Microtremor Survey Method. [S.l.]: Society of Exploration Geophysicists with the cooperation of Society of Exploration Geophysicists of Japan [and] Australian Society of Exploration Geophysicists, 2003. (Geophysical monograph series). ISBN 9781560801207.

PASYANOS, M. E. A variable resolution surface wave dispersion study of eurasia, north africa, and surrounding regions. Journal of Geophysical Research: Solid Earth, Wiley Online Library, v. 110, n. B12, 2005.

PEDROSA-SOARES, A. C. et al. Orógeno araçuaí: síntese do conhecimento 30 anos após almeida 1977. Revista Geonomos, v. 15, n. 1, 2013.

PEI, D. Modeling and Inversion of Dispersion Curves of Surface Waves in Shallow Site Investigations. PhD - University of Nevada, 2007.

PEREIRA, R. S.; FUCK, R. A. Archean nucleii and the distribution of kimberlite and related rocks in the são francisco craton, brazil. Brazilian Journal of Geology, v. 35, n. 4, p. 93-104, 2007.

RICKETT, J.; CLAERBOUT, J. Acoustic daylight imaging via spectral factorization: Helioseismology and reservoir monitoring. The leading edge, Society of Exploration Geophysicists, v. 18, n. 8, p. 957-960, 1999.

RITZWOLLER, M. H.; LEVSHIN, A. L. Eurasian surface wave tomography: Group velocities. Journal of Geophysical Research: Solid Earth, Wiley Online Library, v. 103, n. B3, p. 4839-4878, 1998.

ROCHA, M. P. et al. Causes of intraplate seismicity in central brazil from travel time seismic tomography. Tectonophysics, Elsevier, v. 680, p. 1-7, 2016.

ROCHA, M. P. et al. Preliminary results of ambient noise tomography in the borborema province. In: XVI Congreso Peruano de Geología. [S.l.]: SEG, 2012. 
ROCHA, M. P.; SCHIMMEL, M.; ASSUMPÇÃO, M. Upper-mantle seismic structure beneath se and central brazil from p-and s-wave regional traveltime tomography. Geophysical Journal International, Oxford University Press, v. 184, n. 1, p. 268-286, 2011.

SCALES, J. A.; SNEIDER, R. To bayes or not to bayes? Geophysics, Tulsa, Okla.: Society of Exploration Geophysicists, v. 62, n. 4, p. 1045-1046, 1997.

SCHIMMEL, M. Phase cross-correlations: Design, comparisons, and applications. Bulletin of the Seismological Society of America, Seismological Society of America, v. 89, n. 5, p. 1366-1378, 1999.

SCHIMMEL, M. Frequency-dependent phase coherence for noise suppression in seismic array data. Journal of Geophysical Research: Solid Earth, v. 112, n. 4, p. 1-14, 2007.

SCHIMMEL, M.; ASSUMPÇAO, M.; VANDECAR, J. Seismic velocity anomalies beneath se brazil from $\mathrm{p}$ and s wave travel time inversions. Journal of Geophysical Research: Solid Earth, Wiley Online Library, v. 108, n. B4, 2003.

SCHIMMEL, M.; PAULSSEN, H. Noise reduction and detection of weak, coherent signals through phase-weighted stacks. Geophysical Journal International, v. 130, n. 2, p. 497-505, 1997.

SHAPIRO, N. M.; CAMPILLO, M. Emergence of broadband rayleigh waves from correlations of the ambient seismic noise. Geophysical Research Letters, Wiley Online Library, v. 31, n. 7, 2004.

SHAPIRO, N. M. et al. High-resolution surface-wave tomography from ambient seismic noise. Science, American Association for the Advancement of Science, v. 307, n. 5715, p. 1615-1618, 2005.

SHEARER, P. Introduction to Seismology. [S.l.]: Cambridge University Press, 1999. ISBN 9780521669535.

SNIEDER, R.; TRAMPERT, J. Inverse problems in geophysics. [S.1.]: Springer, 1999.

SOARES, J. E. et al. Seismic characteristics of central brazil crust and upper mantle: a deep seismic refraction study. Journal of Geophysical Research: Solid Earth, Wiley Online Library, v. 111, n. B12, 2006.

STEIN, S.; WYSESSION, M. An Introduction to Seismology, Earthquakes, and Earth Structure. [S.1.]: Wiley, 1991. ISBN 9780865420786.

STOCKWELL, R. G.; MANSINHA, L.; LOWE, R. Localization of the complex spectrum: the s transform. Signal Processing, IEEE Transactions on, IEEE, v. 44, n. 4, p. 998-1001, 1996.

USSAMI, N. Estudos geofísicos no cráton do são francisco: estágio atual e perspectivas. Simpósio sobre o Craton do São Francisco. Salvador, Bahia, Brazil. SBG/SGM/CNPq. Spec Publ, p. 35-62, 1993.

VALERIANO, M. C. et al. Evolução estrutural do somínio externo da faixa brasília no sudoeste de minas gerais: registros de uma tectonica pré-brasiliana. Brazilian Journal of Geology, v. 25, n. 4, p. 221-234, 1995. 
VDOVIN, O. et al. Group-velocity tomography of south america and the surrounding oceans. Geophysical Journal International, Oxford University Press, v. 136, n. 2, p. 324-340, 1999.

WAPENAAR, K. et al. Tutorial on seismic interferometry part 1 basic principles and applications. Geophysics, Society of Exploration Geophysicists, v. 75, n. 5, p. 75A195-75A209, 2010.

YANG, Y. et al. Ambient noise rayleigh wave tomography across europe. Geophysical Journal International, Oxford University Press, v. 168, n. 1, p. 259-274, 2007.

YANOVSKAYA, T. et al. Seismic surface waves in a laterally inhomogeneous Earth. [S.l.]: Springer Science \& Business Media, 2012.

YAO, H.; HILST, R. D. van D.; MAARTEN, V. Surface-wave array tomography in se tibet from ambient seismic noise and two station analysis i. phase velocity maps. Geophysical Journal International, Oxford University Press, v. 166, n. 2, p. 732-744, 2006.

ZHDANOV, M. Geophysical Inverse Theory and Regularization Problems. [S.1.]: Elsevier Science, 2002. (Methods in Geochemistry and Geophysics). ISBN 9780080532509. 